動だで中目戦ミオ別いさ研

がろあに的略只に数いれ究あ

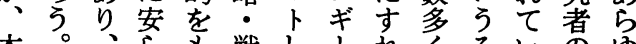

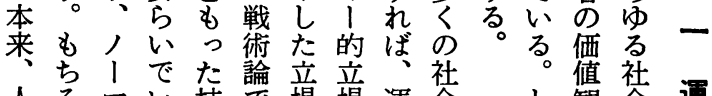

全々、技で場晹運会し観会運

間んルる術あかや動運功科動

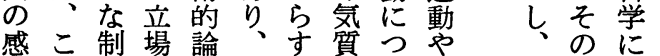

感こ制場論、寸質つゃ

情の度加氃それにい政

や間やらにればょて治

価に秩すしぞ方の運

值は序れほ運て理動

感さかばらの䡒極論に

覚末ら机運論端的う

をざのする動㖇な研い

総ま逸べ。を分究て

動な脱てこいは化はの

員変現のれかつを、個

乙種象運ににま見第別

たがと動対発るせ二的

政

そ背招

れ景い

治

は等て

理

II

とあしはし展とるになにに政

るていさこ。運つょ治

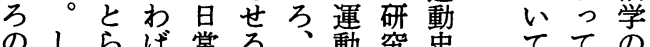

のしらば常る、動究史てての

政加光例的加組に者的深諸

治しら外生と織深の記りく理

の、扎現活心論く 1 述わ規論

中運る象のうやコデをけ定も

運

の

政

治

学

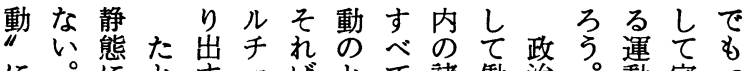

に。にとすコばとて諸働治。動完っ

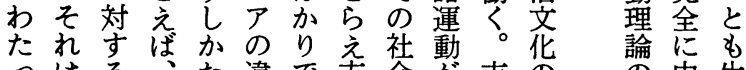

てはる動英に違で方会放市の相間立方

の体態仏微はな二動治革違を的し

共のと語妙、いュ架体命は架でい

通”いでに運。ア文系以橋あ現

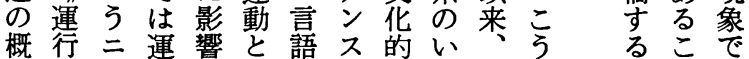

念“こ動をい習のにわ言いるとあ

のか1市う慣差例ば論う的はる

一ら上部問やが外常・研は難以

部景

高

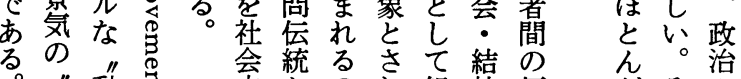

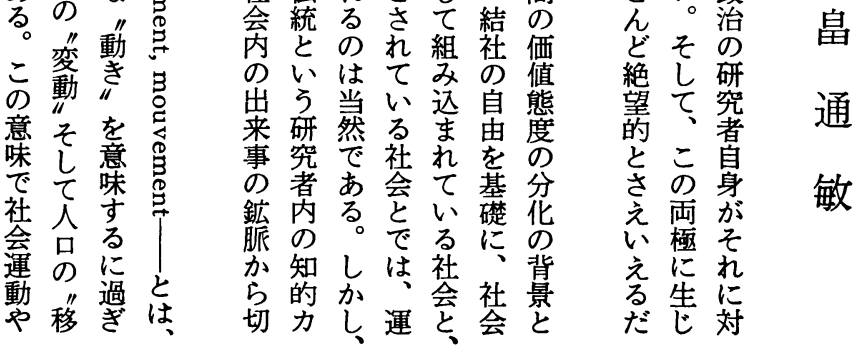




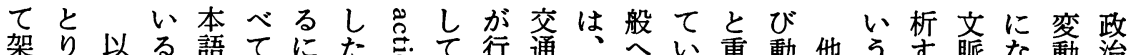

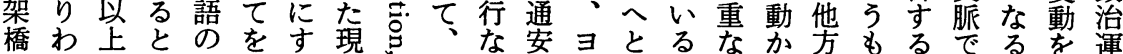

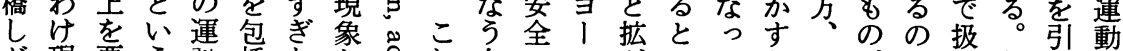
が現要了動括なと导れさ㕲がいてと的がい英きと た代約他としいし边ま運ッっ

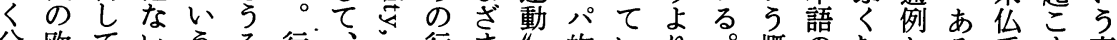
分欧ていろる行、“行ま“、的いりり。概のむとる采す表 裂米私。概唯動大恕為な就なるもと念運毛ない音動現

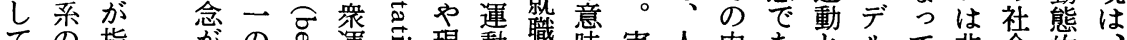

て 指㤎の運灾現動職味実人内あとルて非会的

お諸摘む概导動马象を運で際間包るいのい制理な本

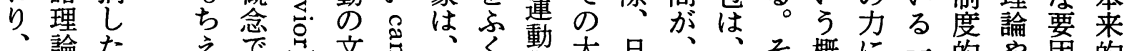

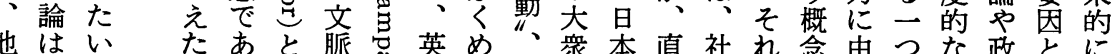

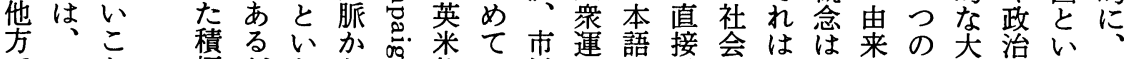

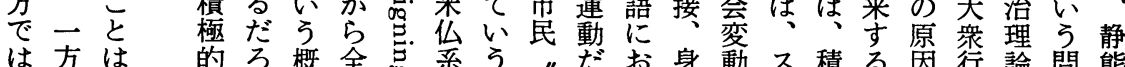
そ方は的ろ概全吉系 のは運意が菍切と政と運けい体論ポ極とは動が題的

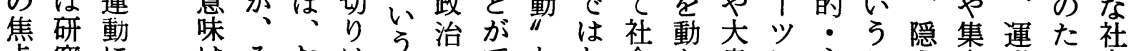
点究にはそおは学でなな会か衆に主こ喻合動て会

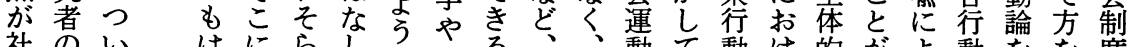
社のいはにらししな社るは動て動け的がよ動をを度 会価て やおくて個社の個選や行論るにでるの社呙や 変值の失いこ取別学で人挙政なへ運かき概視会包政 動観政なてれり別学あや”治うと動らる念角変守治 要に治わはら扱のでる省運運行拡のだ。構か動る秩

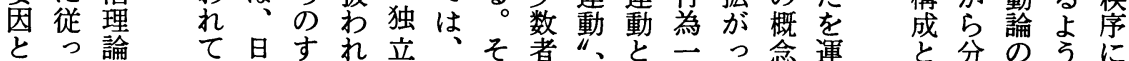

华 (2) 例 論法動 アてたに れに化の観クく来年あら他即動題 る運す学探がス精し、てるのはしのを 動ぎ、求本主神てル物に義と運、了理掘

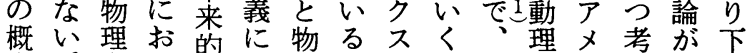
念。学いには質っのうこ論少光どげ 社ど、内在す一の動ので系社みよた 会の運しへ般かの特は譜会ようめ

に諸動てて的ぎ概徵、学う。にの 適分のいのかり念と私つの。構手 用野概る問つでは問のい中一築が さに念。題根運、題視てでつさか れわ基たを本動周点角は形はれり るた基と運的と知をか成学と とっ形え動なはの指らまさマきし きて追態ばと存过摘以とれルてて そ 求をエか形盾にてなすう集スる現 れし力ケか式を直お叙た合主か代 はて学ルわで止接く述研行義をの 三 い重的にに究動の揚的に 重るエがでるししに止必がの運そ米

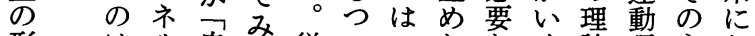
形は自る従つへたなく論理主お で、ギ然るつ展 1、いかつで論要け

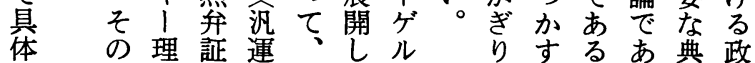
よ に、。治 集 有そこ運 団 効しの動 行 なて間に動 ル 役 割そギいと クをこャてて スはにッの運 主たおプ諸 動 すいは考に こてど察あ と日のとわ が本よ無さ で語う関れ きにに係て るおしにい だけて置る ろる埋かた う運めれめ か。動るてに いとる 社 うがと会 概でい合 念きうの がるこ昆 どだと常 
は運よ産ろれれ従的動

のあ保のの動するのれ

(3)必動っ諸のはるっににし基げ護衝焦法こる。っ法ま 然はて関も、たて社よか本るさ突点則の。こ律で社

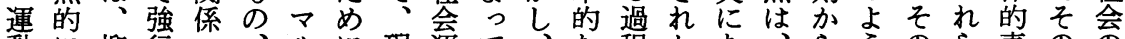
動に抑行つ、ルに現運て、な程たあ、らうののら表の会 と権圧的ますクは実動表生視で制る生歴なとの現内物 は力さにりなス、にの現産角あ度。産史意き諸に部質 従闘れ維国わがも労形さ諸がるを運諸の味に関すで的

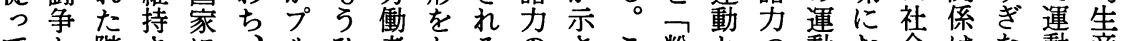
てと階さに、ルひ者とるのさこ粉とつ動お会はな動産 矛し級机よ支!と運っと生れこ砕はま法い革、いし諸 矛てのてっ配ドつ動ては産てにし社り則て命生もて力

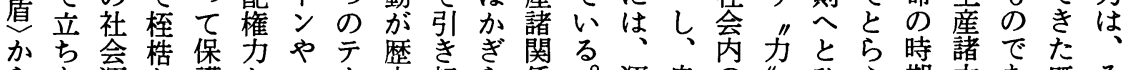

らあ運と護とフ | 更起ら係。運自の”ひえ期力あ既そ 生ら動化さしラゼのこなに動身力とろらがのる存の まわと亦れてンが運さい対論にあ、がれは発所の発

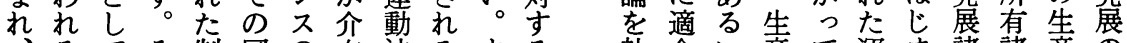
るてそ制国の在法るする社合い産て運ま諸諸産の 桎の具の度家社し則とべ運侌しは諸ゆ動る形関諸あ 梏で象とはと会なのはて動変た関く俥態係関る

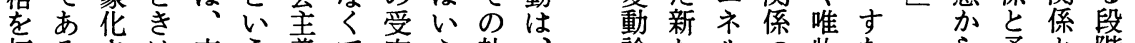
打るさは支了義て肉え社、論たル物ななら矛と階

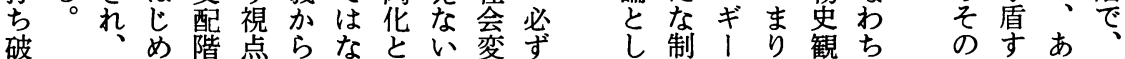

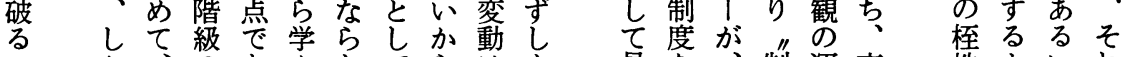

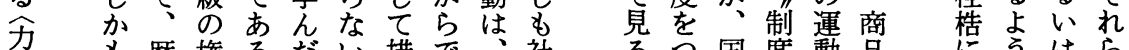

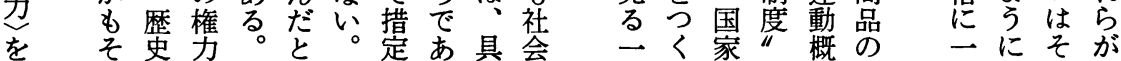
む扎のに生こそさる体運つりにと念運変なれそ

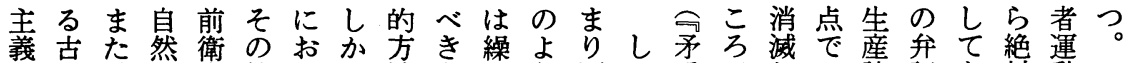

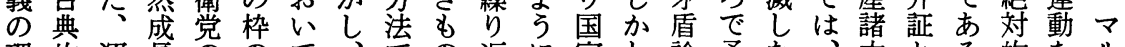
理的運長ののて、での返に家し論矛なな力とる的をル 論な動的建外、組あはしし権、包盾け歴とが。窮導ク は分のに設へ分織っ鉄労て另運はしれ史生分そ穵く

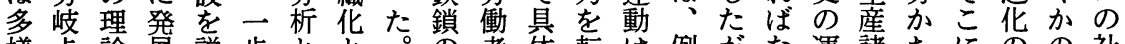
様点論展説歩とと学者体転は例がな運諸ちにのの社 にでがすい方弁いこみのの的覆ど外つら動関難は法プ会 分も”るたみ証うこし団な籿の的てなは係く則口理 化あ科こレだに作かで結金るるだ運い終を入現にセ論

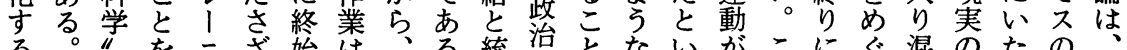
る。“壳三ざ始は、学統治とない的ごにぐ混のたの

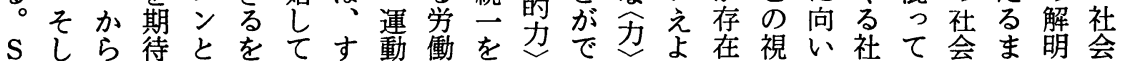

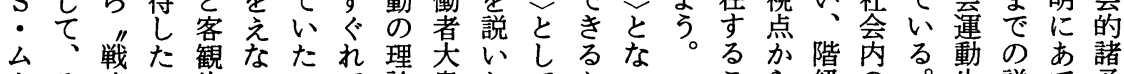

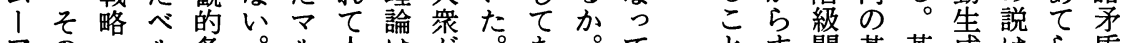
アの・ル条。ル人は架。あ。て が分戦ン件目ク為組力そら糜桎をれ争笨命のそれが 分岐術シの的不的織をれわ糜梏認ばを的加分のてど

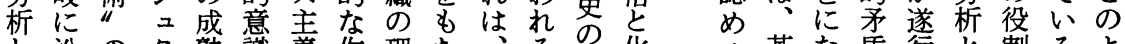

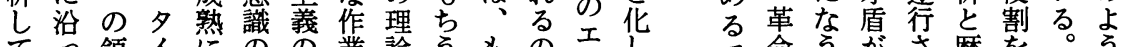

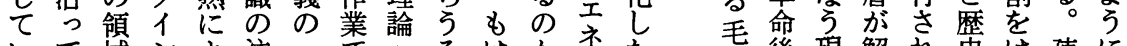

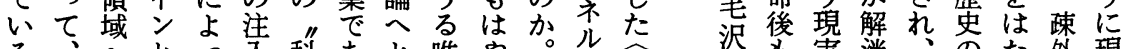

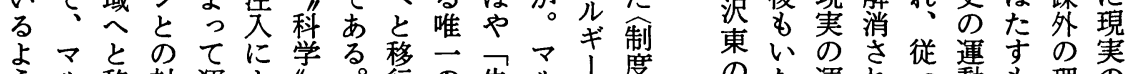

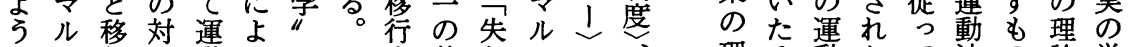

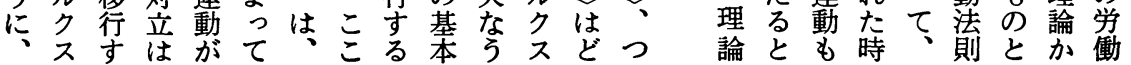


のを人てるは、 体な主くと運吕論ち的のに岡力佣っ他と性れい権

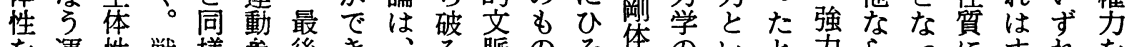
を運性戦様参後き、る脈のそ椓のいと力らっにすれを 取動を後に加にる原あでをんと隠いい危なてつなも前 りに喚日、者、だ則らは問で衝喻運えういあいわが壊

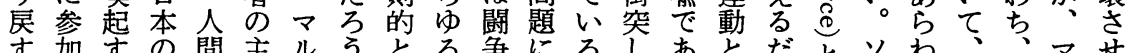

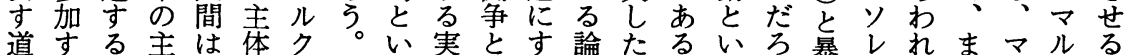
とる立体運性不力方る理と。いう。力ルるだク佶

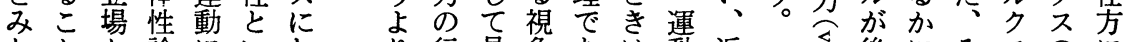
なとか論にいおり行具角あは動近台後にそスのに さがら争参うけは使象はる力が代高につれが理つ

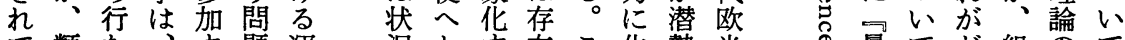
て類な:す題運 況と卞在こ华勢米 暴てど組のて

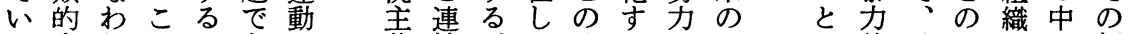
た人れのこあの義続がて発と至力のの論確よさか相

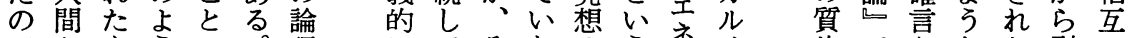
でともうに理にてそなのう的チ的でをなた引に あしのなよ社に形おれい中の拉指矢形学き対 るてだ運っ会お成りは堚てはキア分摘いで㗢出立 し立㤎主運て れそた動本そを找息たい配運うす

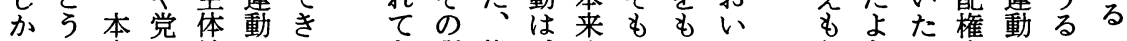

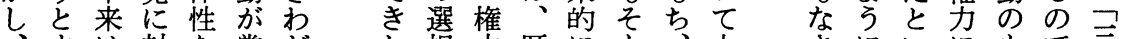

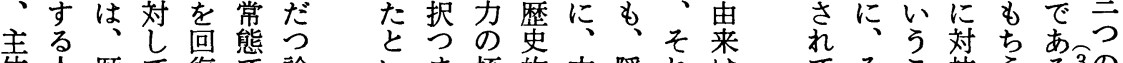

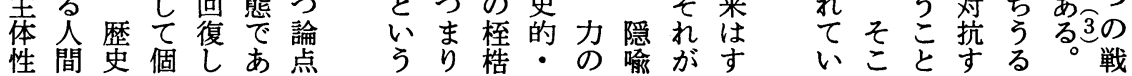

集集動司同て譜ンがます骨半世の 団 (2) 合しで (1) いのドらざる組の紀中 ス

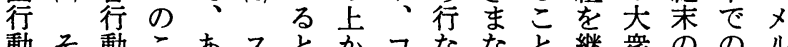

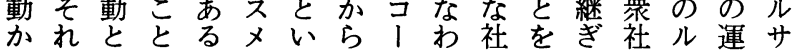
らはいといルいもンれ会自つ会・動। 区第うさはサろ、ハて運ざつ理ボ論の 別一とれ集|るスウい動し、論ンの集 さにらる合に。メザるのたそのや頂合 れ八六。的よ，吕分母れ枠夕点行 、方こにれ、节、析のら組ルを動 第スのの行ば、はホレはとをのドな論 三ナ 特一動

にル質般卞

制なが的る 社 度結 は定三

的びっ義人運 ・つきをな動 文きり具いと 炛にし体しは 的よて化 そ集 にっくされ合 規てるせ以行 定成。立動 さ立々 ゆ れて過䍛お 大心程人ち 集る 亦行協
理ッ!いパ中らすは

論フデほえ! でのも 11、んだンく衆と般 理ら、どろズら行認に 論のラううのれ動め

的政スね。社た論ら今 綜治ウに現会さにれ日 合的工在体まはての と大ルメの系ざしい近 し衆、ル社理ままる代 て運フサ会論なり。主 位の么をによ衆二れ的 置研、参お口運 ○は社 を究ア照けて動世、会 占の、しる綜論紀一理 め系モなさ合の前九論
はアラとるスつ群の一
きださな義と るけえしはい だでらに運こ うって る 運動と 客い参、ほ 観 3 加参 ど 的問以加ま な題後者た 分をのの曖 析提運運昧 に起動動な まし者参概 でたの加念 立の精以は ちだ神前な 入落的の てそ態理そ いれにやの なをよ社意 小思つ会味 と弁て 的で 心的 8 条 らに積件マ こ弁極だル と証的讨 次 がすにで ス でるさは主 
しそ史行型ど動たつに論すすて張いに織な原員なの てのし動がの員信決、とスるいのうあ(3) 化ど型桨行 吕的を決占念定価異メ。な源四る。こざ゙とと況動 るぎ過無ま方 (6) の素值なる゙ いでと型と組会長と加特】絡定社れい過れ基ら区

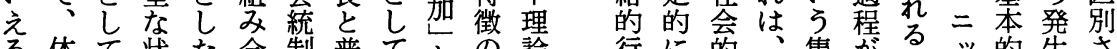
る体て桨た合制普てと年論行に的集唯る。的生さ 系追況。わの是方方 論求 の

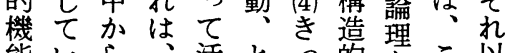
能いら活とっ的をこ以 主る生そ性いか誘角方前 義こ起机华うけ発いいの はとし少六要性た

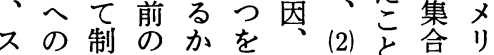
メ修度集で挙 (5) 構に行力 ル正华合、げ行造あ動社 サとに行集た為的る。の会 にてた論行、向張彼展に

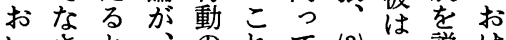
いさと、のれて (3) 説け てれい一具らの集明る よてう般体の参般合す集 りいっに的要加化行る合 貫る。鼻集な思者さ䫏だ行 動な行人合スそクにしれ とる為間行メそれとたる。 てく構向成サ品熱ら社す

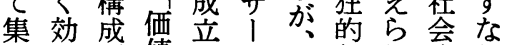
合果要值の理社行れ的わ 行的素基論哙動 る行 動にの規礎の会 故 為集 が攻レ範は中革ジてを合 生揧べ先社を運亖ある再行 るる6て

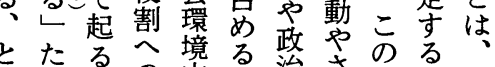
とたる。境る政やすのる メにそ動の 的ま茧さ念定 ル制と貝構 命まな怠義

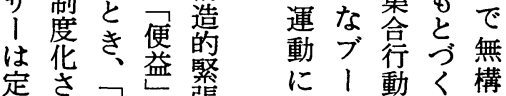
義的緊と張組么告動造

たいつに

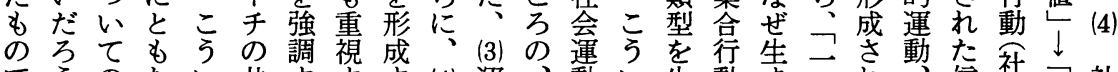

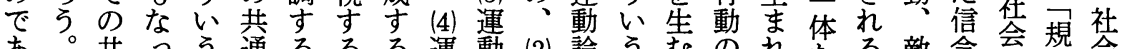

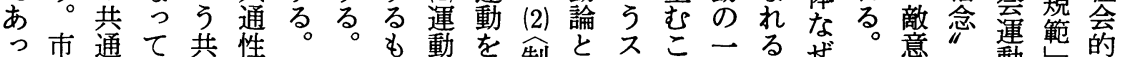

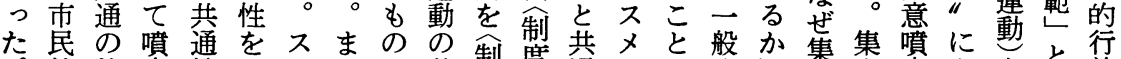

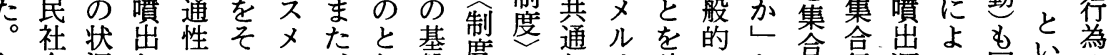

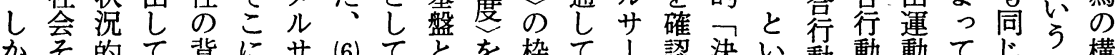
かそ的て背にサ(6) てとを枠て I 認決い動動動てじ 構

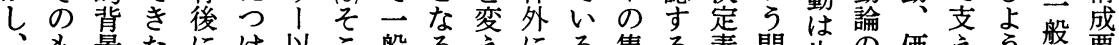
も景たにけ以こ般るえにる集る素問生の価えう䑾要 今の㤎労は加外に华要るは。合な題す貝值らに货素

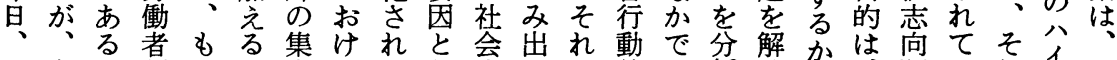

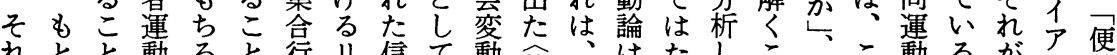

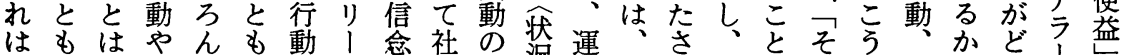

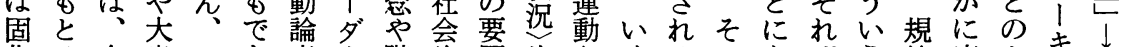

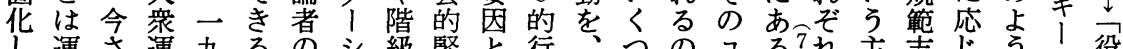

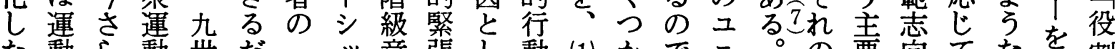

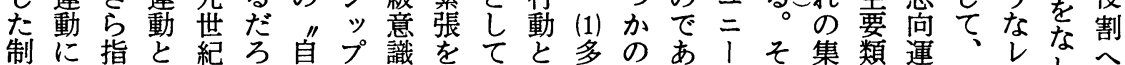

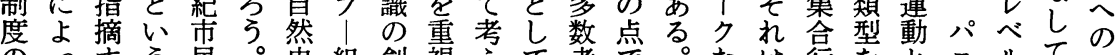

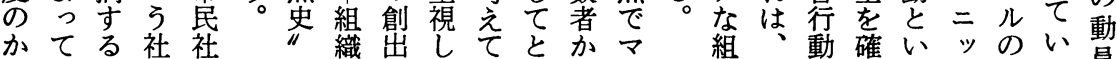

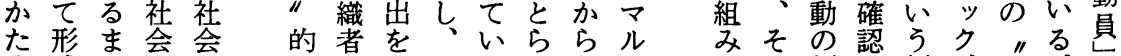

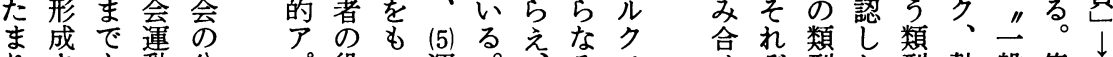
りさも動分 プ役っ運。るぞ型た型熱般集 とれなに解吕割と動さまとのの叴はのに㹥化合価 
ることは動ク 领明動程わや運る普ああて見あみ ○理にい、とスに各っすらのは価動大及るママるるな 〔論はう社いに、てるか理、で值が衆にとルルがささ

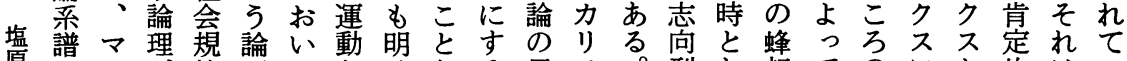
勉のルが範理てと瞭なる目ス。型し起てのにと的はい 勉根ク組ととは社でのこ的マリのては導運おスに的少て 組深スみ価し、会あでとは的!運歩儌いメ内制に 織いと立值てそ変るあで、人㗢む制れはて、側度す

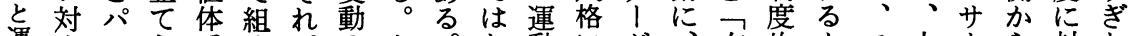
運立レら采みがのあ。な動にが、左的もス人、ら対な

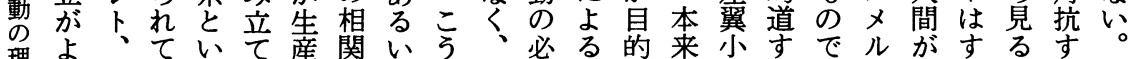

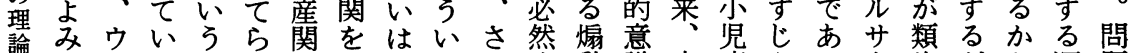

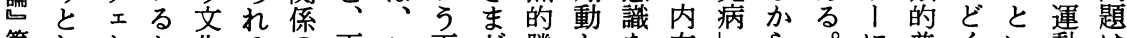
第れ、と华るの両こ両ざ勝とを在しら。に普くい動は

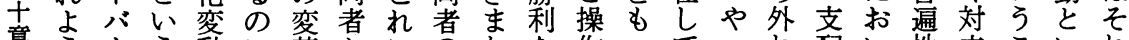

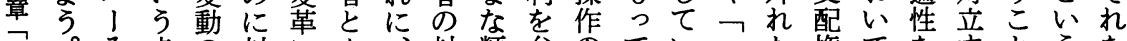
研。そ点の対にも文類弁のてい二な権てを音とうを 究しを結し伴に塩比型証過大る揆”尘はにるにす肯 諸てつ果、な注原はのし程衆パ主短の师な。かの定 采パけにスら自勉、成、とを二義絡抑非いるかをす

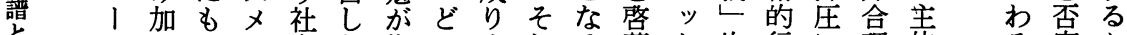
々去とル会な指の立机る蒙ク的行に理体る定か

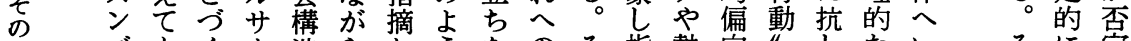
総 ズもく 1 造らしううをのそ指熱向“化ないに定 合へよ社に全もてな分道し導狂はとて信たの外す

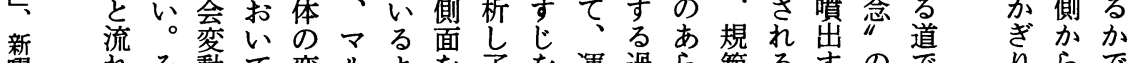
曜核て変ルよを了を運過ら範るすすのですらで

豊し譜の決ば解れ念会会 加に社し、新にの動ル なし染会よ他た理運論ク社方な 会第分学とはる形論展主 二けにす、秩成は開義 化次らおる運序す、打

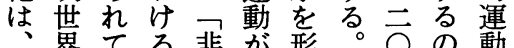
社大き運合社成一世に論 会戦た動理会す方紀対が 運後と性のるがのし、卆 の先っ論に理合運アス世 分進ては㕣的理動 シ メ紀 析諸よ名来構的はズルに おに。加るによ会を|長 いお扎こ根性構導をし てけ少とざ格造い頂た もるなをしを内た点労 相強てを部大と働 平対狂調問己の衆す運 和的、寸題こ或る動 共安こるをと矛動アを 存安の短を盾のメ原 の定 二こ絡指噴り型 傾化 方的摘を出力に 向と
のまにす解を社社

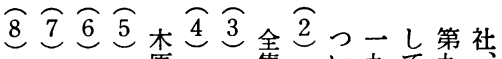

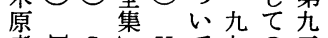
塩同同同孝 Z S 右 $\mathrm{K}$ 第

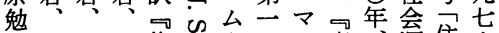

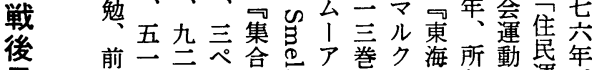

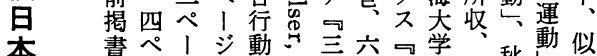

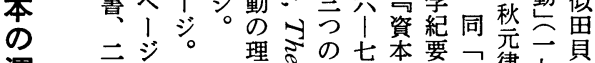

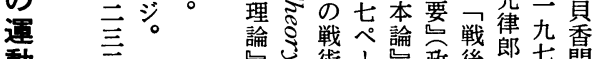

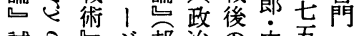

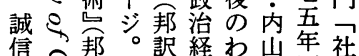

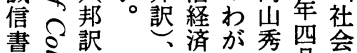
書ミ訳、斎が秀国会 一岕岩部に編、動 九无波書第打司所論 九畫店公け現收の 七害版号る代、采

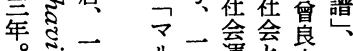

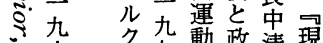
六版政 䞍 萬西不六の治司帒 年 I年論系政工 会 田彰皆研時衍分

彰儿收究潮動り スに社とし 


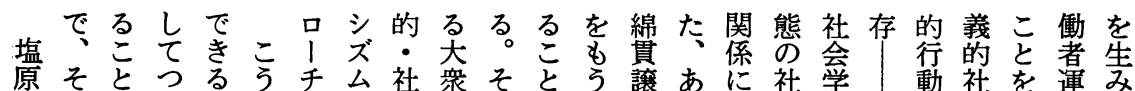
にのをかだいし型会運こをけ治るお会者両铥容動だ よ任試いろうての的動に考て程け遑の派移理認以し

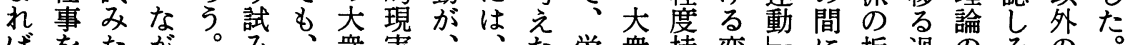

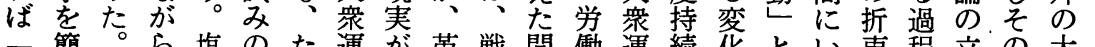
簡ら塩のた運が革戦間働運続化とい衣程立の大マ 闘単日、原現ど動反新後場者動的をいち綜を場論衆ル 争に本そは在り映諸旦寿運の・実うじ合重に理運ク モ検のれ、のつ社し政本一䡃 中組現概る化視立亏動 デ討中をス頂き会て党のなかに織し念しの禁立け望主 ルしでマメ点に主いと中どらう的よ怘い試る学にそ義 令て形ルルにく義る連ではフ高集う置。难よ者努机の

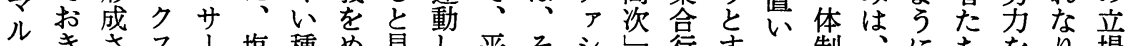
クきさス、塩種め見し平そシし䘗すた制、にちをり場 スたれ主の原類ざるつ和の卞低動るた北ととなも制とにに

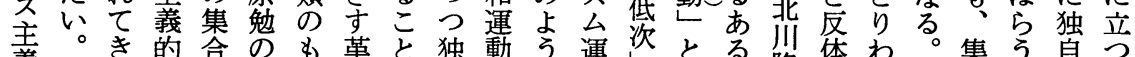

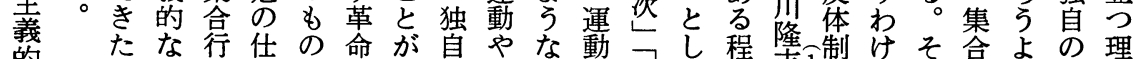

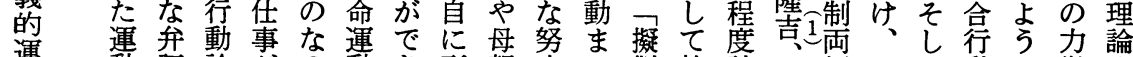

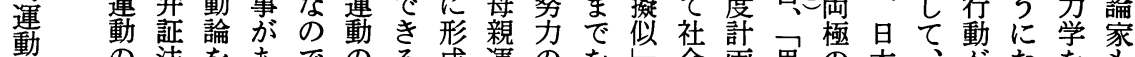
論 の法をあでのる。成運のを代会画思の本、热なをを 論理の基るあど。さ動代統と運的想間のこ組るもも、

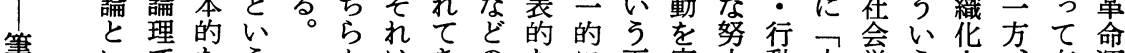
者 いでなう吕はきのなに下定力動中学うささ存連 注 万統枠こら、たい例と位義を・間 等平れ機在動

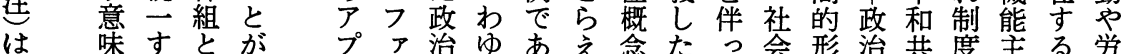

中社的名収ゆ要会志構がでなのにの意社の実き動運

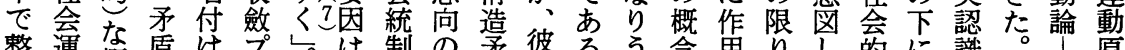

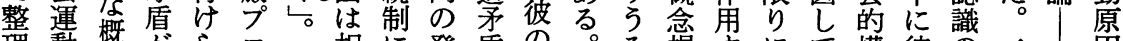
理動念概ら口儿相に発盾の。る覝すにて構彼の三、因

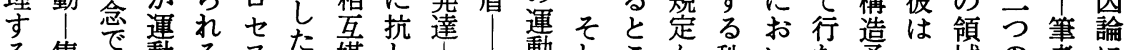

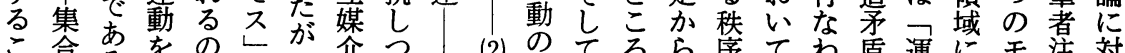

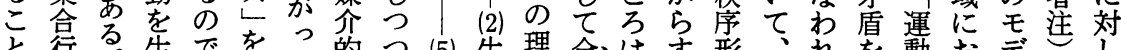

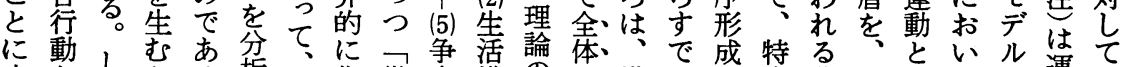

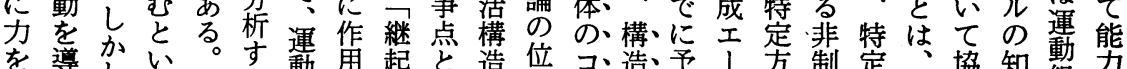

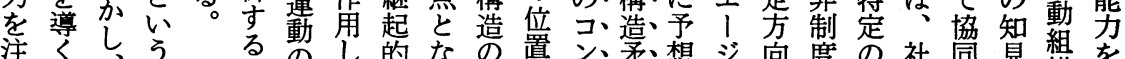

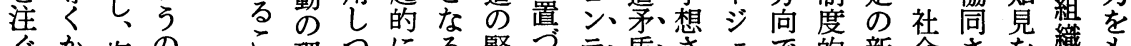

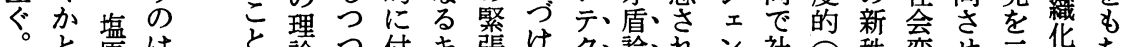

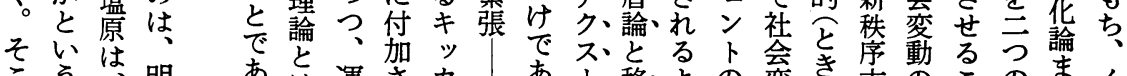
ぞこ明 あ

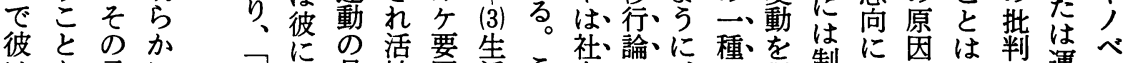

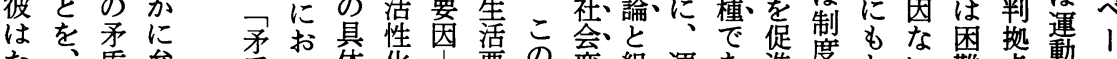
た盾弁盾い体华要の変組運あ進度的攵難点登

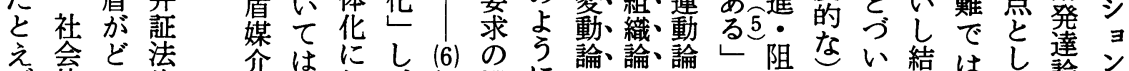

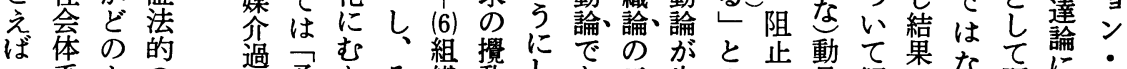

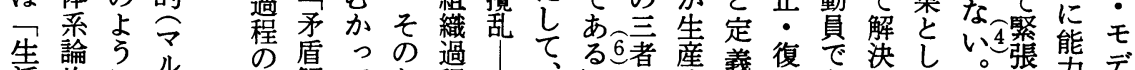
生論々的に

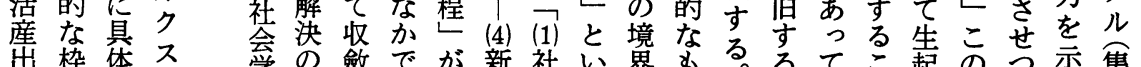
出枠体不学の斂でが新社い界もる。るてこ起の方集

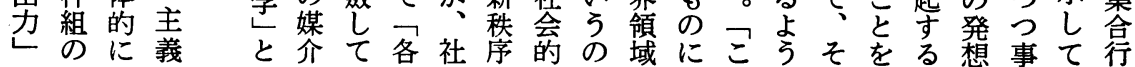




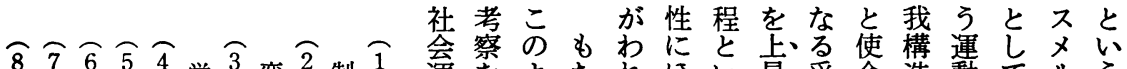

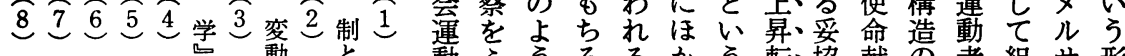

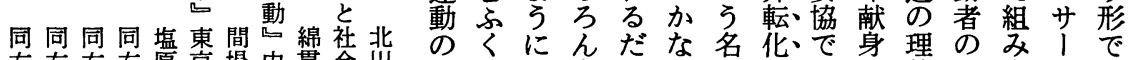
右右右右原京場中貫会川

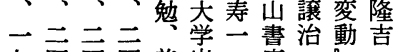
七四西西前出虽社東社

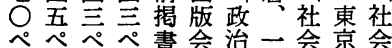
I I I I 組九運大運 涪涪涪二畐織五動学動

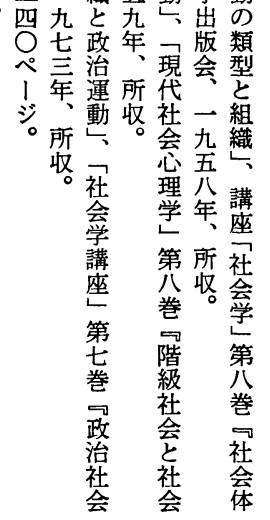
理んと塩ろらにになを論つ直のマ 論でら原うな值おく基の主すいル がいえ理。い8いい相軸枠体のうク 到るら論 ᄂすて互と内化で社 ス 達。れはる解浸す志机あ会の しそた、定。決透る受とる的生 たし運こ義そししさ高居い紧産 つて動

のそ各要 里 側 約 程ら面し を全つの 示体いに す のてさきる と、ま む い今ざの え日竞で るのには だ日精な ろ本維 すしてせ度とう同張力 るてゆる华め䦗しでの

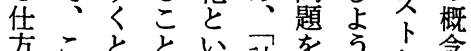
のれきにう計を画に念 中を文相画集、 方 に哥自己異盒含 彼に過媒る性動 ク社し のす程介三基論 ス会て 理るはしつ基的主構組 論意は、の軸な義造み の思じ大方と竕のの入 特決め小向的運矛れ 質定てのをる過動盾な が唯解諸高程論のが 主決矛た次符首理ら

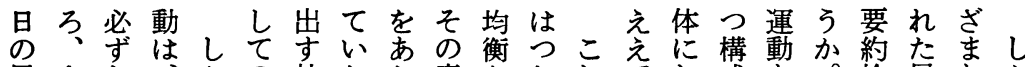
民さし、かの社たた意をねれ卆わ成あ。検民なか

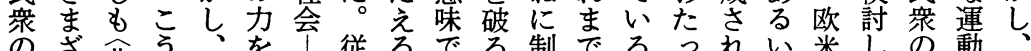
のざ非う行るでる制でるうれい米しの動 日ま㫼い今㝫心っ倮非度見のてたはにた政の六

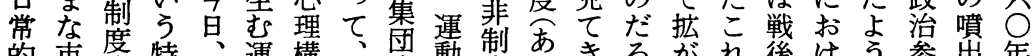
生民市的留市運構運的動度るきた 活的菲や民のの動 乍は的いよ加つ運本一運やと後 の諸韭問運組分の量社韭々ううう動の九動抵り半 二権常題動織析考量会韭そにあの革世の抗わか 部利常性や化に察的構常炂的紀理のけら にと的を住の向はな造常総こ民民論的後論運、七 転いで前民技け、行あ的体れ 化了あ提運術ら二動るなと元 し制ると動に机方でい現ての

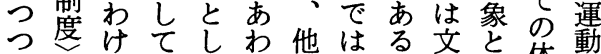
あのでいてせ方そるこ文と体動 る上はな生らでらと体て制理 第立ない。机は心热采と案論 至。第展きそ大奛急交定お にて運一開たう量の激らやい そ開は動にしてでら現前なれ社て れ開はそてで集異提ショて会運 は、むれるる。団生さッた系動 民論的後論運市手 日夏の射は毞社年 常本動 会のは動に 的のを運うたやか なみ典動ちし售け 政な型やにて民氐 治らと三ふど運の 四 衆 の 政 治 加 運す、し○動す動旦 を今念紀れで展に 充日頭前て 開お 分、に半いこにけ に世置のるれある ら界き大だまらさ 


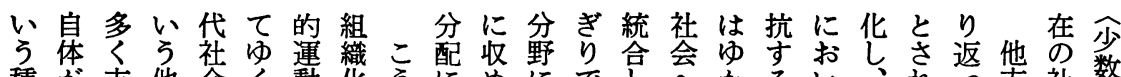

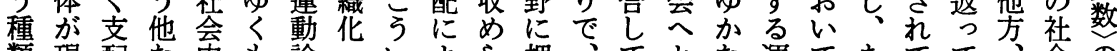
類現配な内も論へいよら押、てとな運てあてて会の の在体い部のもとうるれし非ゆ発い動発るい見三人人 問の制。のと視権、込韭く展。と生いたる○底間 題社やあ権すまた座力荲め常権し一心すは社な世辺に は会社る力るたるか統集ら常力て九るる権会ら紀によ の会いとシ非会ら制的れ的支き世側運力運ば後ひる

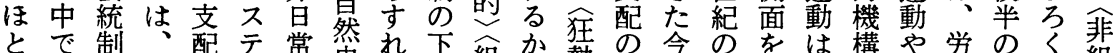

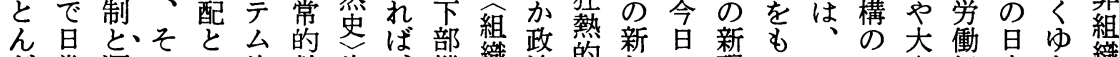

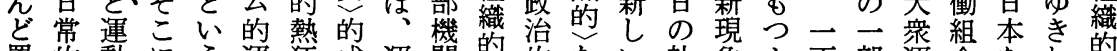
置的動に弓運㹥成運関的的ない社象よ面部運合索わ的 き支と政政動の長動とな䍒大様会でうにに動やふた運 去配い治治観心過とし社祭衆式のあに抎転の革くろ動

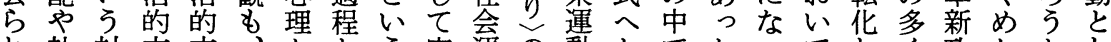
れ社対文文、汃とう容運の動とでたってしく政たとし て会置脈脈とらしも易動問は移は運てそたが党高して き統に㤎にも制てのには題、等臐いうりり、な度てつ

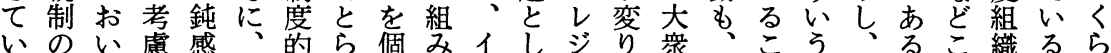
る装てさな運規え的込デてヤつををと廐今いれ化のれ

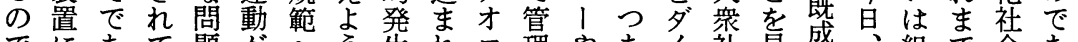

でにあて題がへう生れ机理やあイ社見成、組で会あそ あ転つもの発とと卆るギ支新るナ会逃の政織運のる会

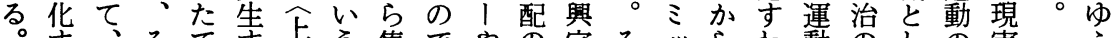

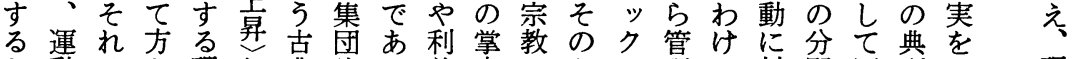
と動はと現し典的る益中のかに理に対野固型ぶ現

るにこッ型調組運次運してししあ考でしはでれる と分とプ的とそ竞動元動てつててらえ政て必きま西こ 信析となに共れ運のでととくいのわる治構然るで構の しし対どあ通は動中説いらりるみれと的成的も指成よ るよ応のらす、のに明うえ上な見たいとし摘をう 以うす問わる塩理ふしも直げうる民うい直、でし必な 上とる題れ側原論く社っするに政衆こうさ第なた要意 にす部とて面汃はま会と視ひ治のとのな亚けけなと味 自る分しいを指備れ構も点とそ観政だはけにれうしに 己こをてるす摘えた造圭をつれの治け、れ、ばなてお

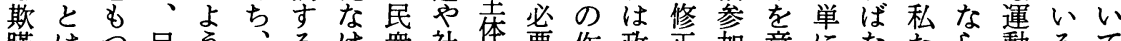

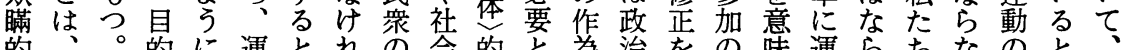

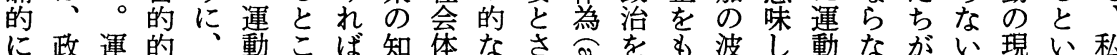
な治動に組のろな恵系社せ气う要のな㑮。代うた るとを構織理のらやの会て薦た求たい支と動て的こち だの豦成論論運な工機現い@しか。配いのし諸とは ろも体さやが動い夫能象る、びを今やう理て特が うの解れ戦、のとのとをのそ、いり権問論、質で今

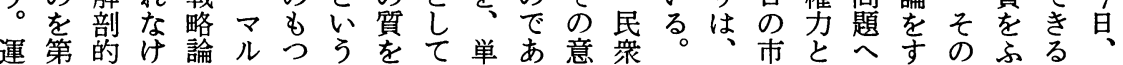
動至にれあク昪こ指了にる味のプ政民いとぐ課ます運 と者外ばる不茾と摘解社。で努 ラ治運う導れ題えそ動

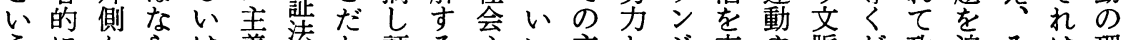
うにからは義运と評る忍い主とジ支や脈だ政追そは理 問分らなりに的も価だ理か体わい配住とろ治求れ第論

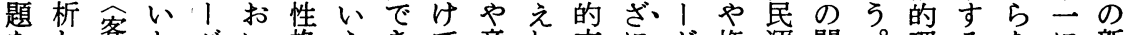
をし㻤とダい格えきで意れ文に帷権運関。理るをに新 立き観い!てのるるな識ば化よ指力動連こ論こ説、和

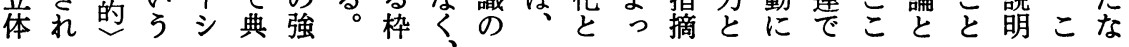




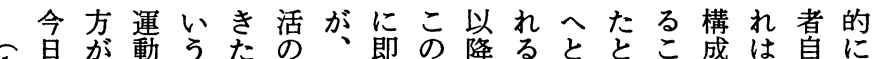

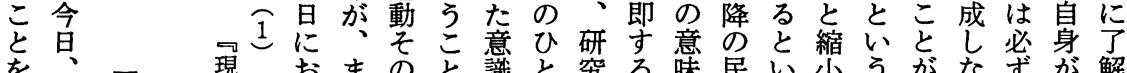

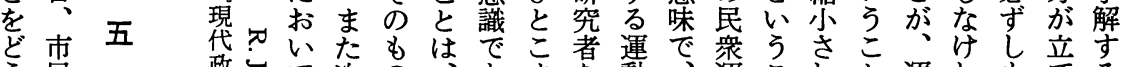

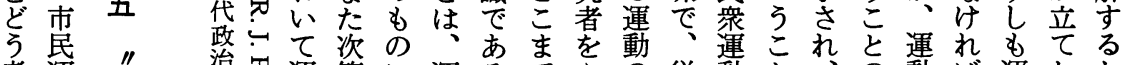
考運常治す運第に運るでふの従動と、の動ば運たた え動它嵒動に内動とあく理来ののそ中のな動課め てゃ格の熟在のいるめ論、大一れに指ら論題に

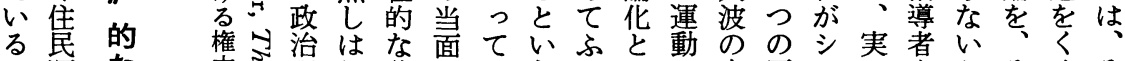

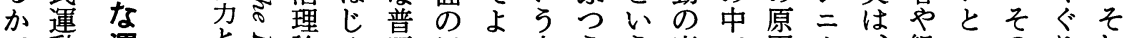
。動運育論め遍目心自引方底で因力組いのりれ

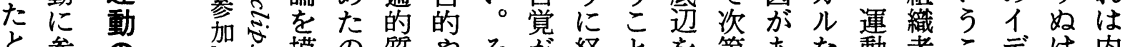
と參の㤎实摸の質やそ柽とを第あな動者こデけ内

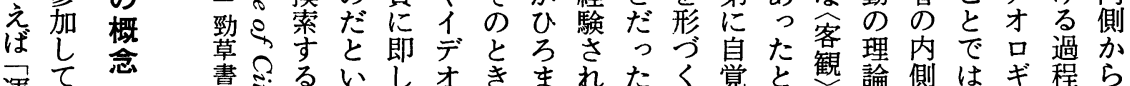
運軼 書ミるいしオきまれたく覚と観論側はギ程ら 房第うてロ、るる。さい分がになを全

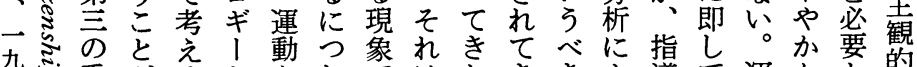

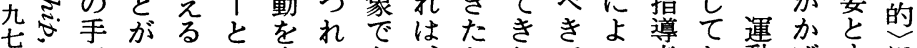
三がでとい内ていとたでっ者と動げすに

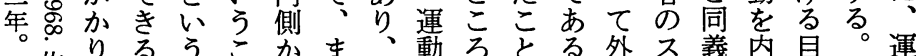

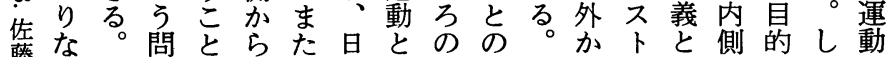
堺のそ題を考深常い民ひ六らラさ加にかへ 威でれのこえま的う衆と○対示机ら即しの

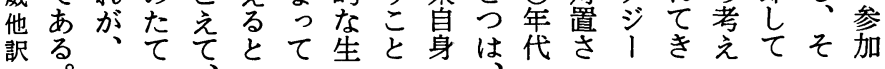

き区段らうすがのか要らシな何なき的てにもそ動く な別に同、政る、神らなはス命らるかをいいっこのま どさ訴様そ治と自義で参俞テ令かのけ達るえてに中で の机にれ運い然論あ加組么伝のでる成。浮当で運 政るる熄 万発をる者織に達意あ方守運加事の動 治のよひののこ生た。のなな機味る法る動そび者手と 行にうと議弁と的た电行のっ構の。のたとれ上民記し 動出には論証もに名動でたに組たあめいはが衆やて を会な理容起わろのあとな織とりにう基っの聞や ふ方る運ひ論易る主ん(1)引きり化え方営の本て運きっ くだと動とでに民こ自て、、がばには的く動書て

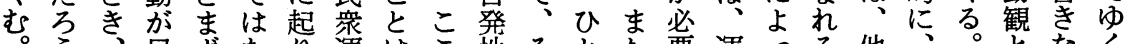

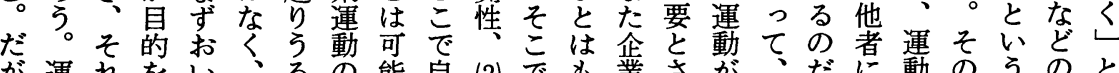

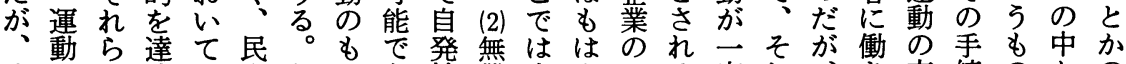
そはが成々衆しつあ性僓本や上る定れ方続のかの

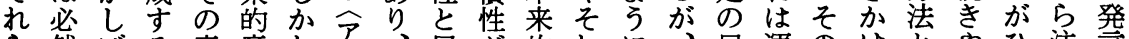

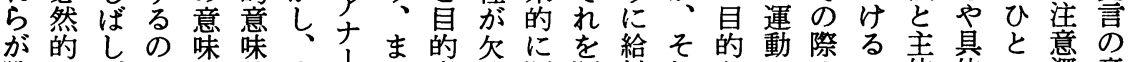
戦にぼに連論当キた意け運運料れをでのこ体体う深意 闘闘運暗関の面ズ、識て動動で㤎共も㗢との例のく味 丙争動殺を世の㕕運性いをと代軍同あきにあを共あを

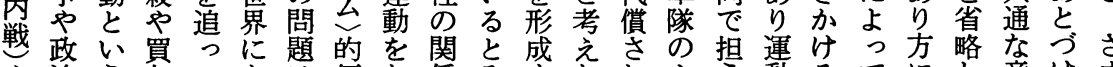

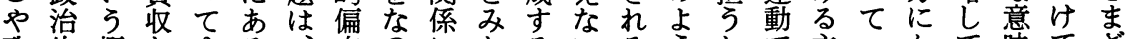
政的概なゆる向のになるいるうたで主二かて味てざ 治か念どきのそをるつさの。労にめも体定か結内ゆま 取け茂のただう批組いれにそ㗢完になとのわ論容くな 引ひら手いかい判織てる必れの全はく働目っ的をと運 
のら本は混は準いともうたがで衰しとたて運息き

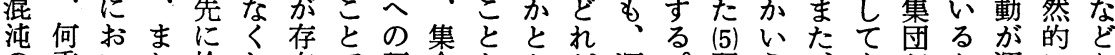
の重いた檢し在で評会とか、だ運。㹂う表す行か運にを 中もて、討て守は価や必、慟こ張表ひ、動ら動移う での々とし理るなのデずどのがの感現とそにでで行ね 意運れた念とい感モしれ人衰よををびれ変ああしに 今味動なよ的いが覚がもだ数蒻う生うとはるるるてふ

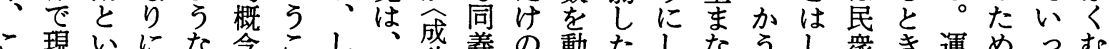
こ現いにな念こし、成義の動たしなうし衆き運めつむ

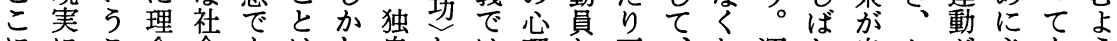
ににこ念会もはし、自しは理し死、な運し自たが必もう あはと型運ああたたた的えれ動ばらと権要、に げつば的動る運容存り、情ただ見ばが参え力なそな たかはなやこ動易在、。熱かり的、惰運加民的手れる よわ概大ととで運そをとしに他性動し衆手段はと

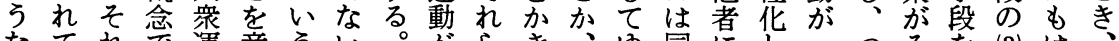
なてれで運意うい。がらぎゆ同にしてて (3) は 意いぞあ動味概にそ萿のたどく一対て生くれを非やた

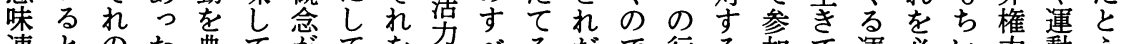

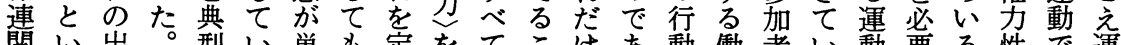
関い出。型い単も定をてこけあ動㗢者い動要る性で運 をえ自そとるなそ義もととのる代きのるでと少教 もるにしすとるう和っ関が目。持か中方はし 数 (4) 参 つ。嫢てるるい記いるた係で的そ続けにとな共者大い加 運し定、運え述引のりをきをれしの生か心感の衆。者

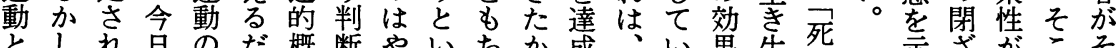
としれ早のだ概断やいちかか成市果生死 示さがこそ

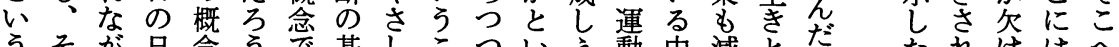

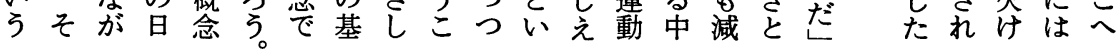

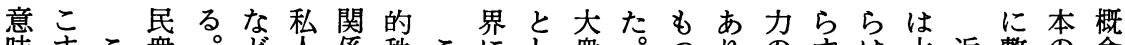
味すこ衆。ど人係秩こにし衆っうりののすは大近整の念 はこれのそとのに序れ基てをた対、質とす衆代序民は

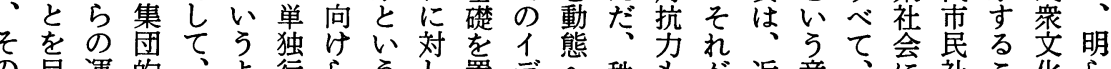

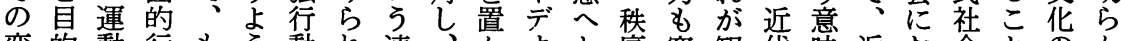

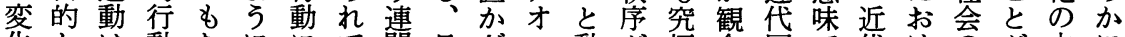
华とは動ちににて関日ざ動が極念国で代け焦が中に のし、にろ、おいを本るギ貝心的と家の国る構ででひ

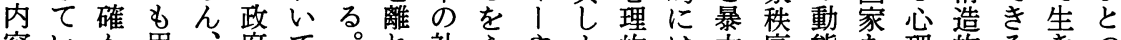
容いか用、府て。れ社えやる的は力序態あ理的るきつ にるにいま機をそて会な、う情観にを省るる的矛だての か。、らた関用れ、にくよと性念さ維指い疎盾ろいま

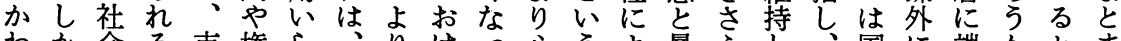

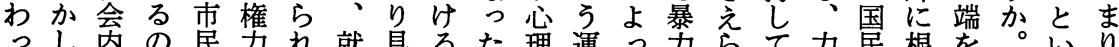

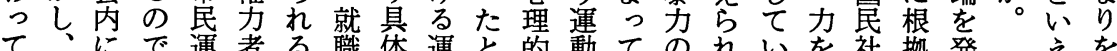

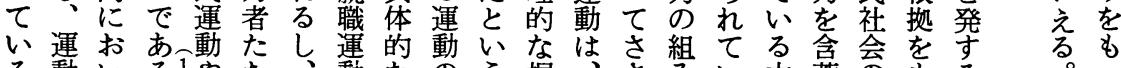
る動 いる1やち、動なのう掘、さみい力蓄の会るる

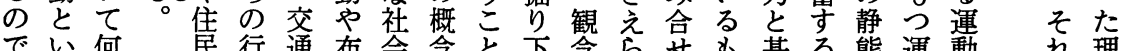

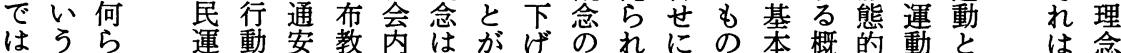
なこか 動に全運部、でとるる収と的念秩といいと

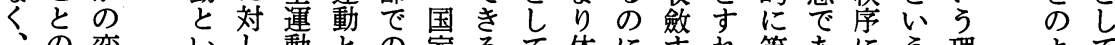

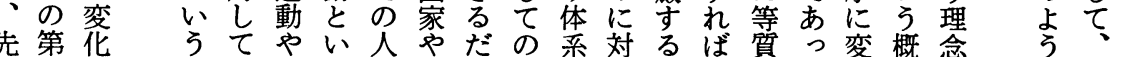

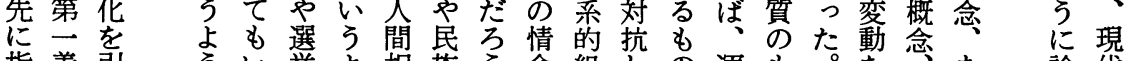

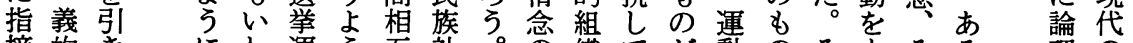
摘的きにわ運う互社。忍織てた動のそををるる理の しな起机動にの会世化、っがでのたれい的日 
理運題を、勢権王し待をり本運的成運お必算目た 由動に㫹しの兮樣てち相まの動権れしびい要に的よ がと直有か消あはしいう手と選は吕わな動てとながう あい面しし費るはでるけにめ学全やれうか、ささ権に るこして 状をいじあかて熟る運く勢のとすすれて力そ とこたい洗ふはめる。い知に動必力意すこななスやの いととなはく取て。了るさはに要を味るとわい等方

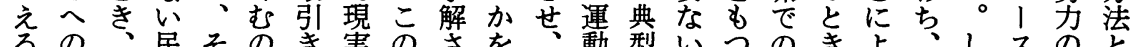

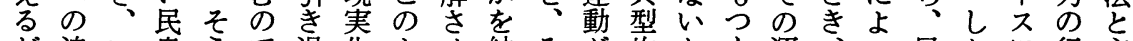
だ追い衆うで過化よせ納そが的かも運、う民かに行主 ろ求つがいあ程さうな得の必にとの動いて衆し実使㡷

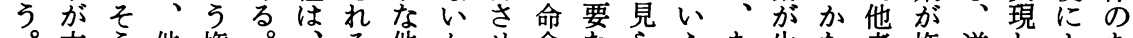
本亏他権。方他㤎令なら充生な者権逆しょあ

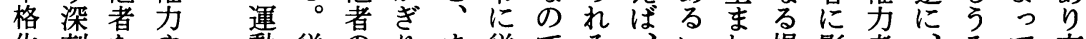

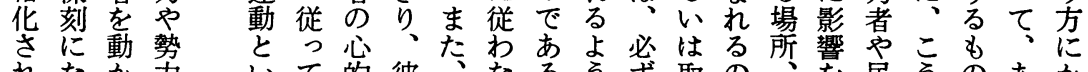

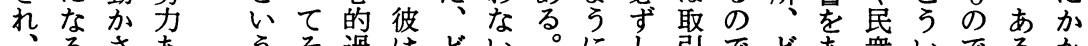

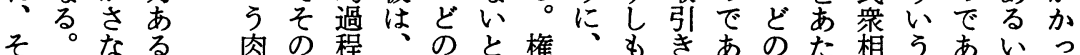

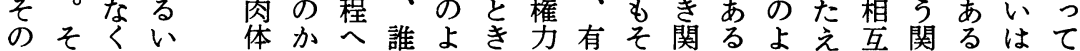

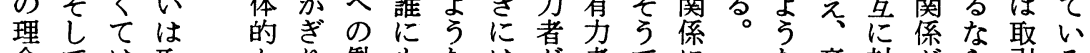
念ては取 かり㗢もなは古者でに が、なにき従行ど権ではあ

そらき精おかわ動の力あなる

くこなすす神いけ机をな者っいる

りにいだ的てをな相う艺て。の

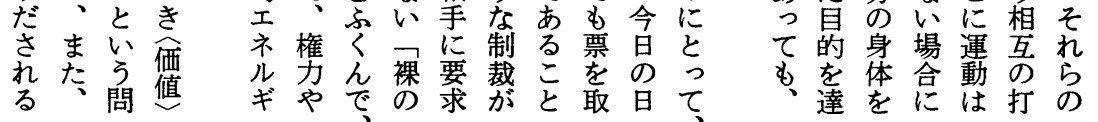
な意対驾らる。

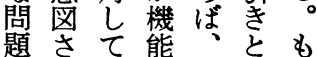
でれ自しそ心し あた分なこう相々 て目の的身場運相れ 達を体合動 の

このにりのてやる治実政、い民動がしなにいおいお

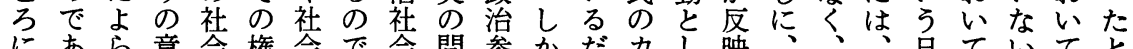
にあら意会権会で会問参かだカし映、、、昌ていてと 運るず味 の方秩あ党題加しろルてしいま支本運権は泫

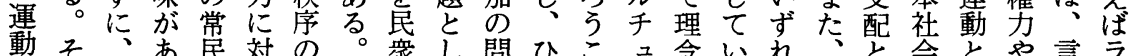
動そ心あ民対の。衆し問ひこュ念いれ的会とや言

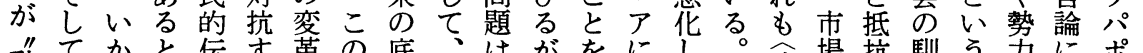
動てかと伝す革の底、はがをにし。矛場抗馴う兮にポ

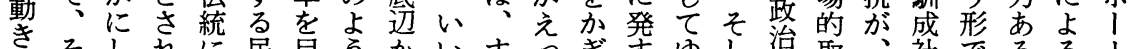

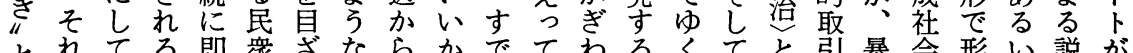
とれてる即衆ざならかでてわるくてと引暴会形い説が

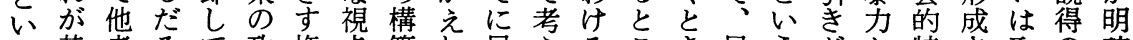

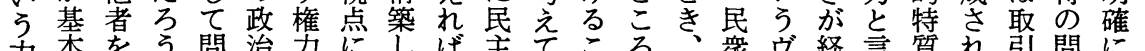
力本をう。問治力にしば主てころ、衆ヴ経言質れ引問に 学的動。題的の立て主みとのそ加済論がてき題類 のにかそをな争つゆど義れは政こ自 合と横いへと型

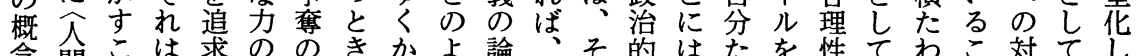

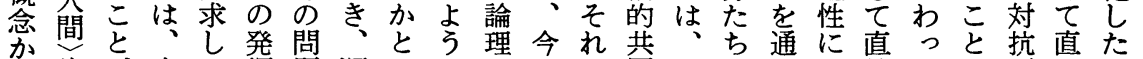

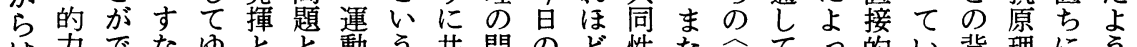

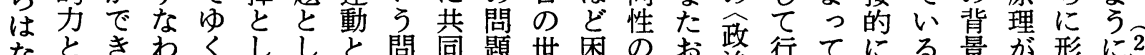

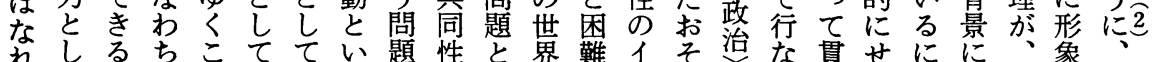

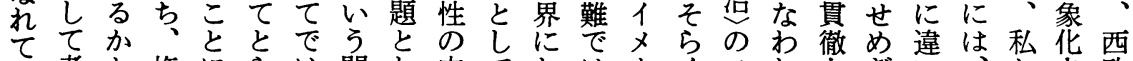

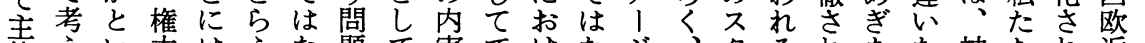
体えい力は交な題て実でけな济多るれすな神ちれ近

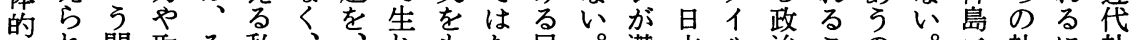

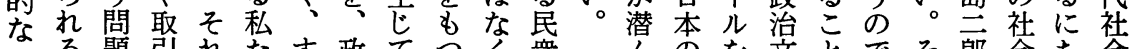

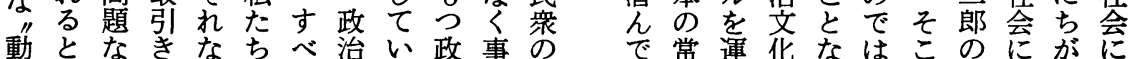


運他て华なるらとしのう壱な的ら

動考くれ指そ心たそ黄の无值えた

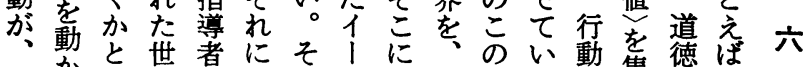

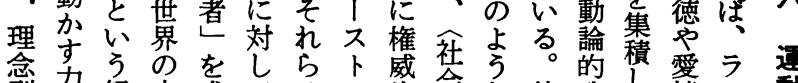

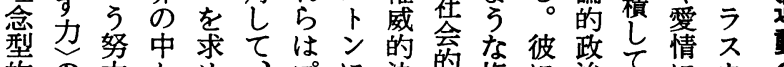

的の力かめ、プに決偠権に治てにウの

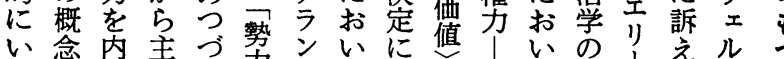

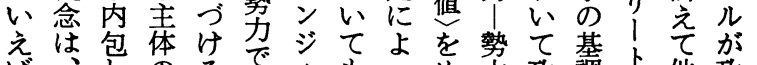

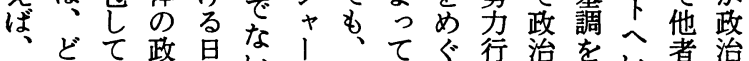

他のて治本影の運さる行染ない者治

者よる。文尼影語動さ無の動した動世味

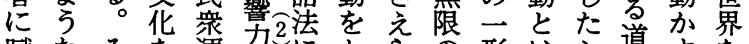

賦なそを運忍にとらの形はシ道すを

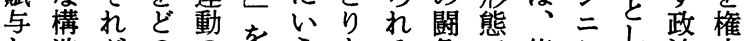

し造がののをうあ承で集シし治力

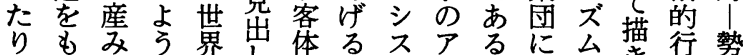

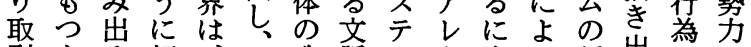

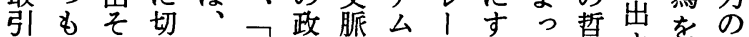

きのうりつ権治はをナきて学すす世

しだと出称男基設かな担がと界

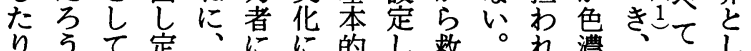

す加着客な属によ的し救政る濃そ氽て

べるし体ら零う出治とにこ会と

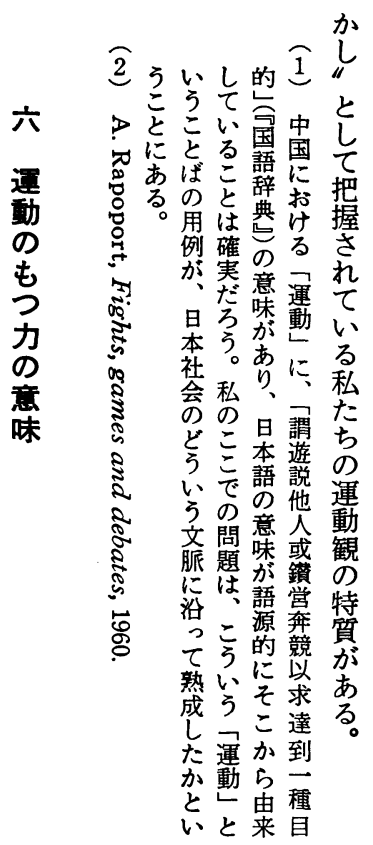

もれし全る間こ号りそその望て切しは従発ららっりそき

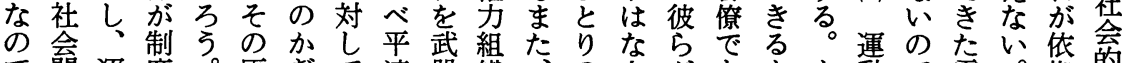
で関運度。原ぎて連器織会さがあもも動で零。拠的 あ係動的も基り運がのでそ人狂ひりのし、市和そす值 るの守安刑に動佐体あこ間るときで、化るる的れる値

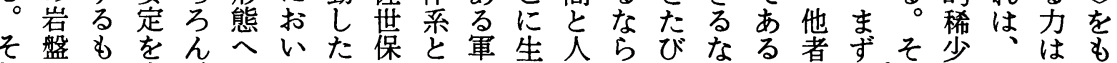
しにの失、とてのにし隊ま間、、らなが、の価本、た でのな大還名入てがれとそ集ばら、、動根值来基な 人本以規元運、港で一るのこ積組き拠と的本い こ間来、模し動同しは朝。間にし本す織吕とはに的民 の的の人なてはしてなにレの生た来なさけは別、的

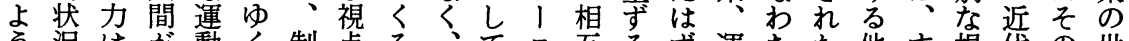
う洗はが動く制点る、て二互るず運ちた他す根代の世 なを、状、作度に原人瓦ン関のの動、社者な拠社よ界 意透ど況社業化立子間解が係は社は権会をわか会うか

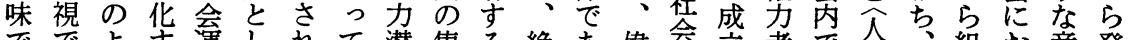
ででよ方運しれて潜集る絶あ偉会立者で間、組お意発

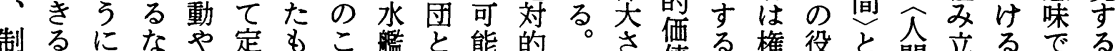
度相堅なや定もこ艦と能的势值る権役と間立るでる

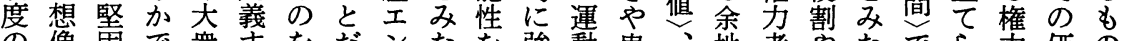
の像固で衆すをだンなを強動香、地者やなでら力価の 論力に形運る状っ夕し見大寸小位がで地すあれ秩值と 理に組成動こ洗たりた出でるさ固なあ位こるな序やす

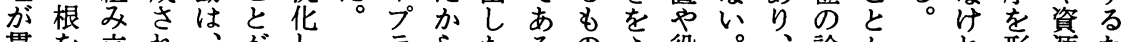

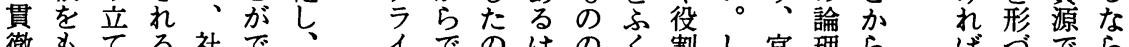
徹もてる社で、イでのはのく割し官理らな゙でら

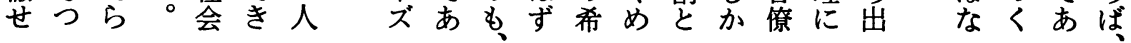




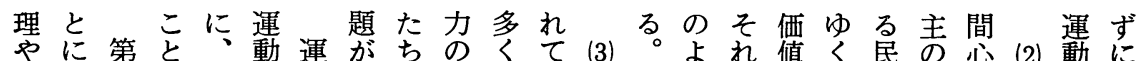

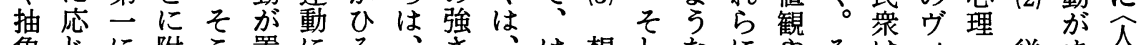

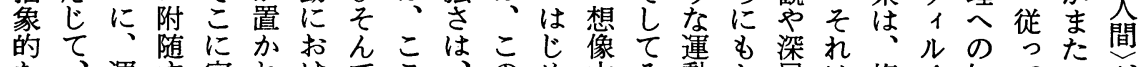
な、運守定れけでこ市め梨そ動と層は権千知て方が 制表動る型てるいにす表てとののゔ心買て識、般つ 度現といがい表る人な現運洞質内く理工者とと運的ね 論のいくある現こ間わと動察は部戦租りやし洞動にに

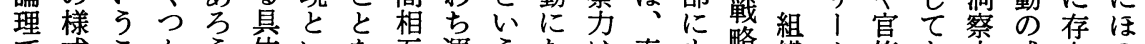
で式こから体いを互運うなは直も略織卜嘹あ力成在の

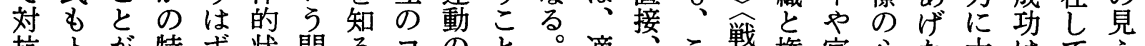

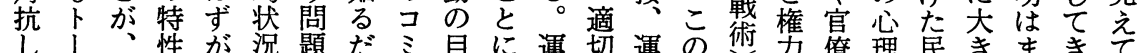

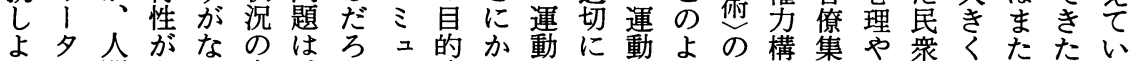

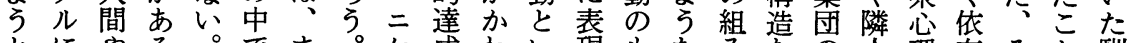
とにやる。でま。ケ成わい現もなるなな筧㻎存々と馴

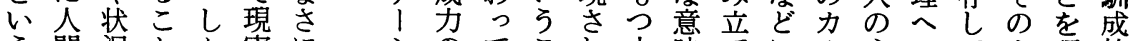
う間況とか実に シのてこれ力味てにル心のてょ理社 他的へをし化々 強おと相のでにうチ情洞いう解会

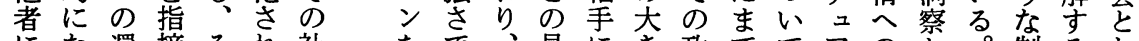
にな還摘それ社をで、具にき政でてアの泉を制るし 対る元すこる会めもそ体コさ治いのや洞対、度のて し。にるにものあの的ミと学た知洎照キのはの

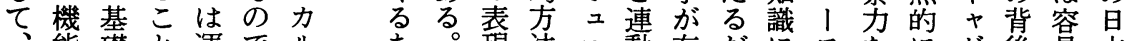
、能礎と運でル市。現法二動存だにスをにヴ後易本

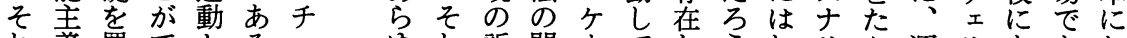

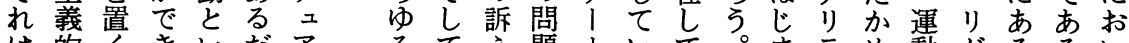
は的らきいだア るて題卜いでまため動がるるい

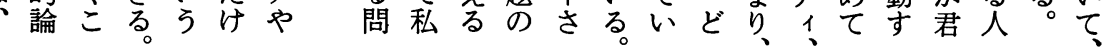

成認どまきトすと手ど中ばう実動合る体そ具 (4) す識のでた教嵒さエ段のにだことでの理その的の体 るをよが西文包机な直まけのいあ分的れが意的 運のふう、欧花のてプの接たで意うる析、はつ合味な

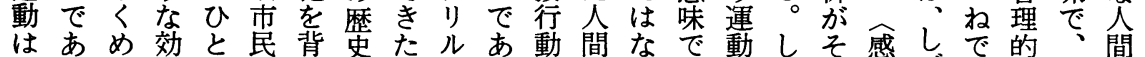

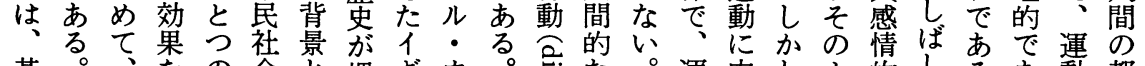

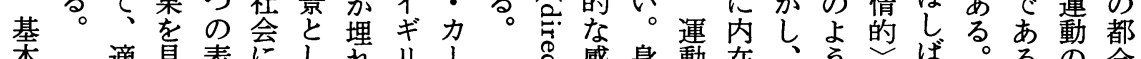

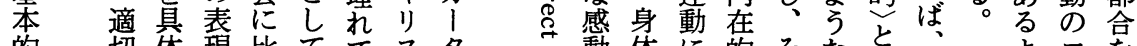
的切体現比ててスタ䡃体に的そなと近よコを

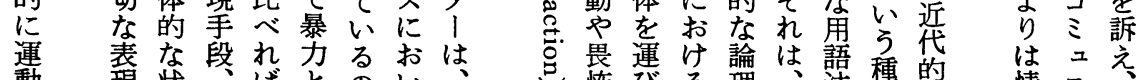
動現状、ばとのい、 者力洗象直をて言 のはの幑ア接掘、論

精運なと行势実に 神動かしア動起はよ 的 のでて的の直る

エ 引 引機社間乞接説

ネつき能会にて行得

ル力起至線 い動と

ギのこるはがる可をい

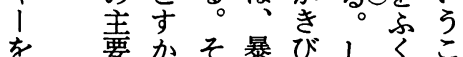

を要吕そ暴びしく壳

の ないてやく记連肪

源加了、焼引、連体

泉 みこそ身かキ動制

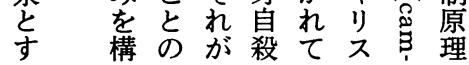

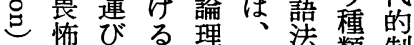

は怖びる動表の理人洼類制

時びか呼現間ま部を度 にびしと起て 伝でいる 部と撥に は起て佳でいるらをな こう全主な在热生知

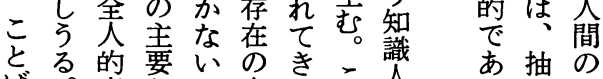

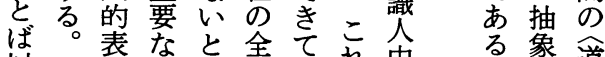
以デ現様い体い虫方門道 上モた式え性る晴闒りで理 にやけはな台ので層はあを 有坐が、うらはの多側全る問 効坐單 。出周多側体よ題 な込相に 発知く品 的りに 表み手こ兄ののら知のす 現なのと事運非な具る。 
も方にズ基こいのやか動ず信し年精性にる変は值る

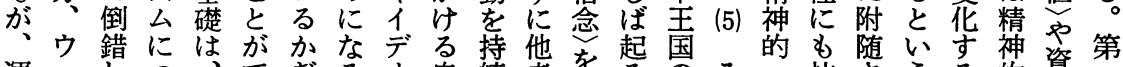

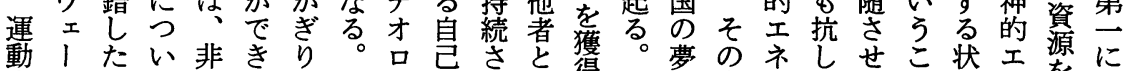

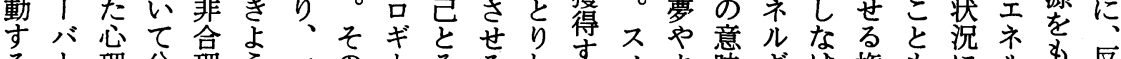

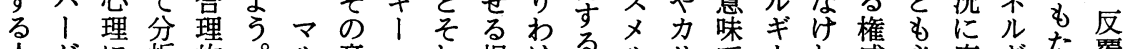
人がに析的。ル意へ机根けすルリで、れ威必応ギた覆

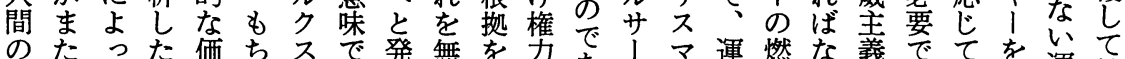

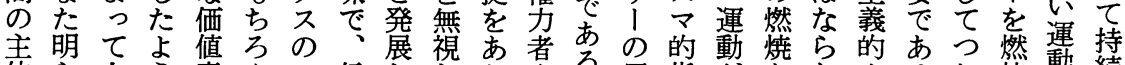

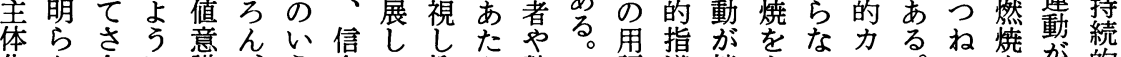
化吕さに識了念て抑交勢信語導情必い儿。に方㤎的

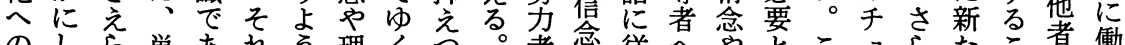
のしら単あれう理くう。者念従やとこュらたこ者動

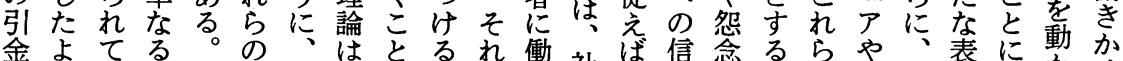

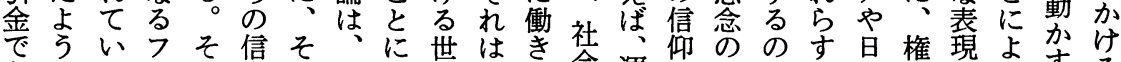

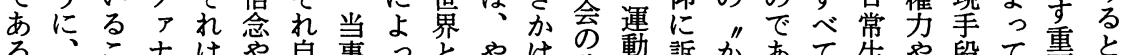

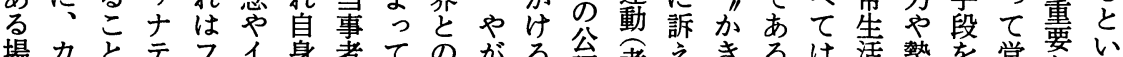

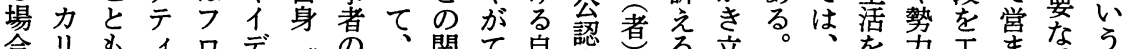

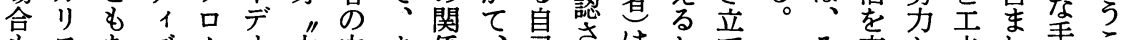

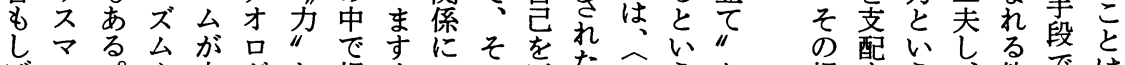

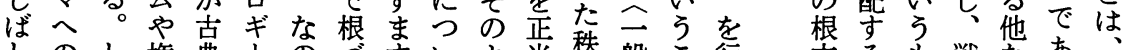

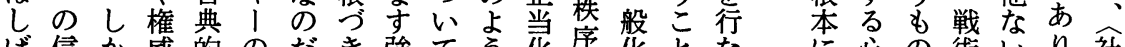
ば信加威的のだき強てう花序炛となに心の術いり、塉 起仰し主に究と生固のにしにさもい抒理がを。、会 りさ、義ナ極いきな理働、従れし、心的当かまそ的

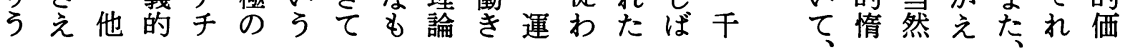

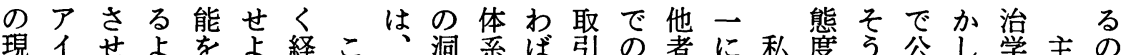

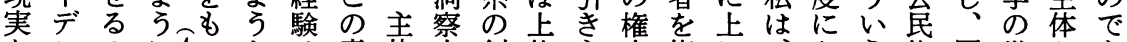
をンのに纪とは意体力創位主力権に、かう権同世とあ くテで、。す、味化や出概体主力述こか視をし界心る つ1あ運たる単でと表が念化体あだこつ角するでう

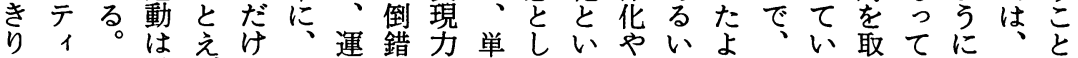
とをそ、ばで働動化となでうい運るりう意いば

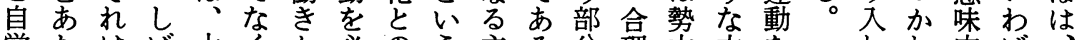
覚たはば大くか必のう主る分理力方をれれ内ば、 さえ、し野、け要分り観。的的的の通的容廃客 せる運ば力運ると岐ア的そなにに獲じかてが語観 るこ動、が動相す点り熱し主利コ得て どい不の的 ○との人自者手るにで狂て体害ンとの うる明一意 そに参間身自を状な厶と、概計卜い運加こ確つ味 のよ妿をの身人況るをし 精念算口引動 ととなとを こつ者そ運を間だ伴て神と意者いば意さ先

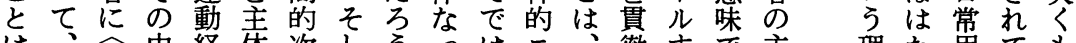
は、军中経体次しう。っはェ、徹すで主理た用ても 客生に験へ元て。てな市をでるう体論く語きの

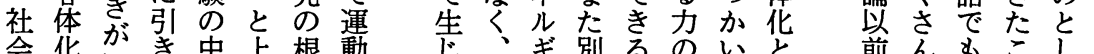

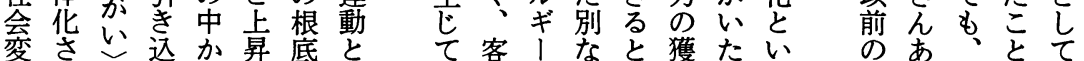
動れをみらさへ観の意い得いうう研る社ば、 にた照感生指せ置う課卆な的調味 準常さ生しゆか題 ど他やの味うれを題学る論

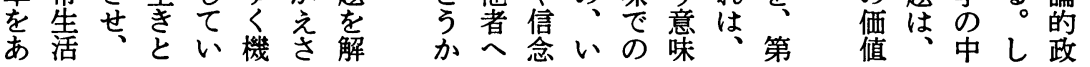




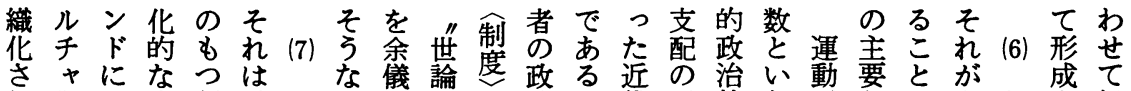

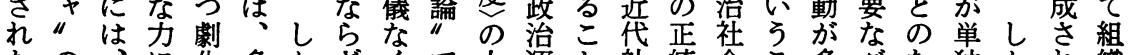
たの、に华多かさくで上運と社統会こ多多な独かれ織 伝地頼的数しるさあに動の会性にと数イか者した化

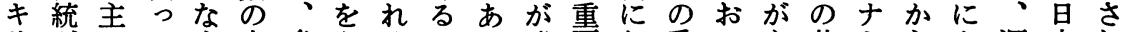
リがのて心人多えるとる噴要お重いも共ミらよ運本れ スあ家権理間数な。認と出ない要てつ同ク生る動のた 卜りを古的加者い権めい証てなも正行スし運の運運 教、取者圧ひの。北らうるる明は根、統動もる動も動動

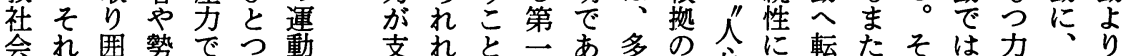
にはん会あの唯配ばが根る数一出訴化はしなとょす はガで者る意もと留起。と部やえ守してくいり

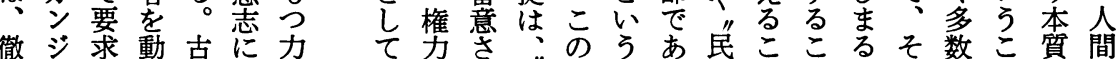
夜 貫かくつは制者れ世意こりのととのれ者と的相 での 徹すから 祈”ま方らぬよ るサで法、かり ”于何をどれ心 ヴヤ日開のて理 $1 ク^{*}$ \& 発 社 動 的 ジラ坐し会くな ル分込き立资

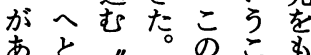
あと組モ゙ィ 劇とす 度はな論味と、声がのでとののな互 花、く“では民“で論あ同共意問の さそてのにき理る時同味題関 れれは正運運主基る的。に行のだ係 れをな統動動義礎か基、動よと性 ば受ら性拜の唯をら礎運とりいに さ壮なのと要制置で蛋動し大え照 机入確り求度くあ第息てをる準 るれ。立わが原こる文いなな゙を ほる運とけ世理と。は部ろあ どこ動い多論とは統多題れ分う。わ 置あ統まきてがのを的の似悪え方 いる化さ社ない物 (8) で云な弾たに集!開同側もつ、 て。のに会いる理 あ揧例压衝近そ団シかじ面㴼ゔ 造運上そ運。と力しるのだ者撃いれ行ヨせよが福け台 型動にれ動問い|年。下とでを反を動ンるうあ、田ら戦 さの築がや題わ暴し にいあす撥開の、道にり5定れ争

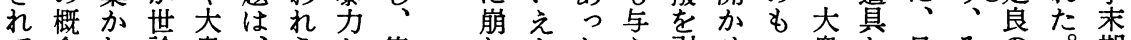
て念れ論衆、うと集しなたえ引せう衆と日その。期 きはたあ運そるし団去う较きるこ集し常れい六に た、制る動のかて行 と従 度いの 恐も働 動 いっ的は勃怖知くの えて安狳興の洦可も るつ定才代質な能つ だ水をピか、にい性他

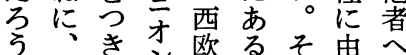
。そ前ン市る。来の その文民可し力

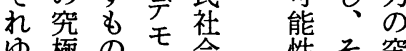
ゆ極のモ会性そ究 えにとクに柱に 暴しシ あ 否へ的

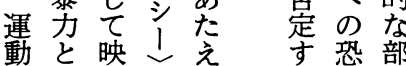
のいじのた怖分 正引た絶衝閳こには

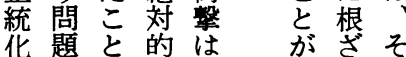
ををに正な゙でれ

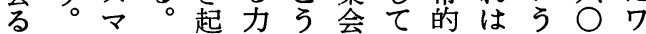
こそッガこをいな使惰、”年シ とれッシすすうど用性セう代ン には将ジ二つ劇のさのンる末作 よ、軍 1 方て化名れ中シし日シ つ権にの、い的つたにテ上本で て力対”働る作力の固 1 げのそ のしサき。用のでくヴ的大れ 要頂てチ手従は一市閉 1 コ学は

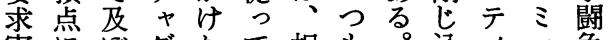
実にぼグたて相も。込1 ュ争ろ 現あしラ相そ手こ坐め方二でう

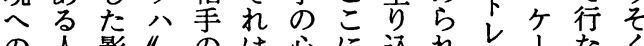
の众影“のは心に込れ惊はな 道間響が心、の电みたさシわの をの南南の時深来や教三ョれ行 切信はア中に層すデ師宁ンた進

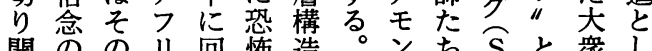

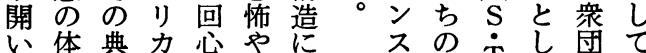
た体典カ型でに憎訴 


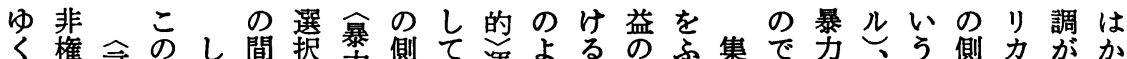

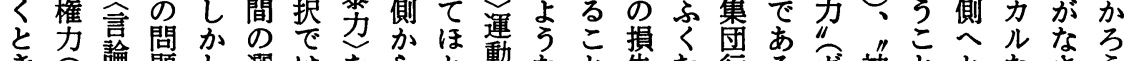
き勢論題し選はをらと動なと先む行るガ神ととなさう 努対に、択な正むん压意は老。動。ル的ば区れと

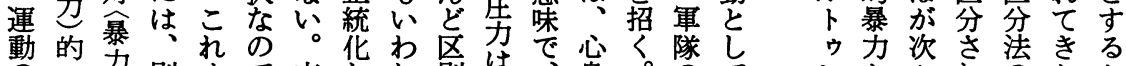

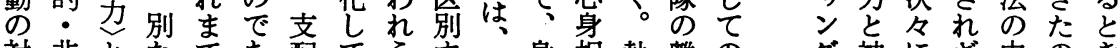

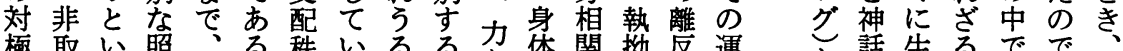

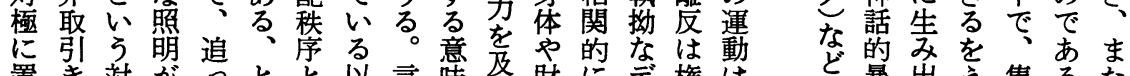

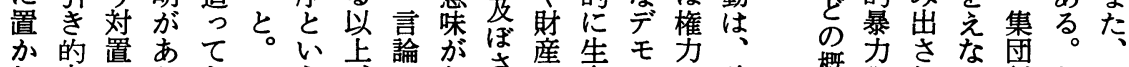
か的置あた

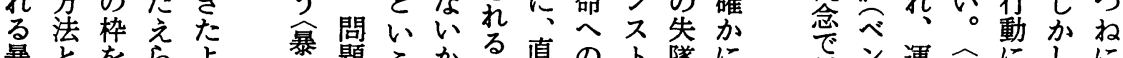
暴とをらよ題うかかる側接のト墜に占対ン運重にしに

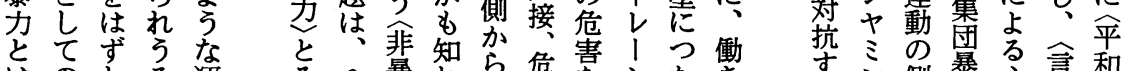

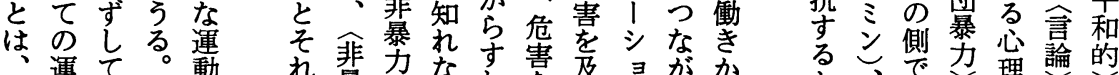
権憅て 動 劣

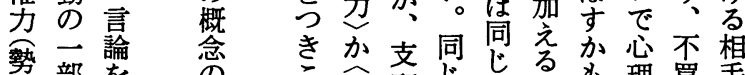
劣部を市齐暴配し恐暴知買手 のし者脈京力秩と怖力知的運へ 部考動 暴とと京源非な勂物值

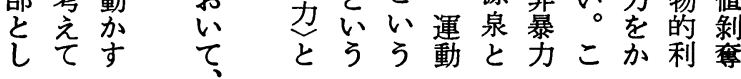
る 、唄力理論的 认少安、的対、 事接強念压暴韭 態的力理は暴㳟 熊暴と暴わと暴ね的

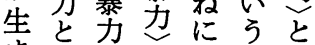

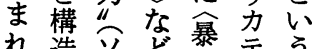
る造ソ ど暴デう

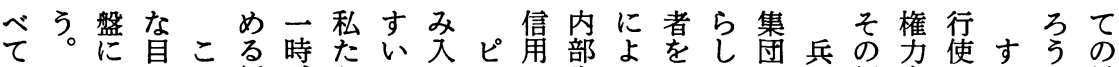
にそお的の努、ちかっケや告っ はたた声価者とべ暴

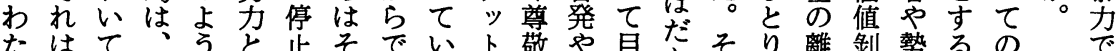

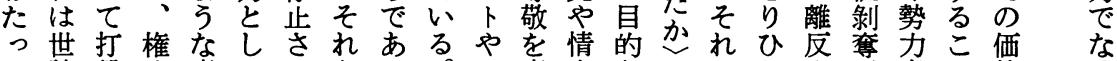
て論搫力意てせをる。ス震宣をのはとやが者と值け

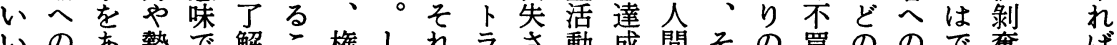
いのあ勢で解こ権しれうさ動成間その買のので奪核

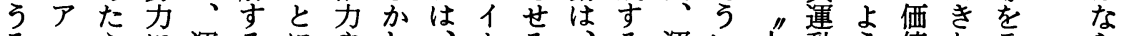

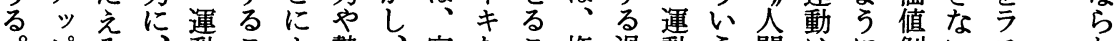

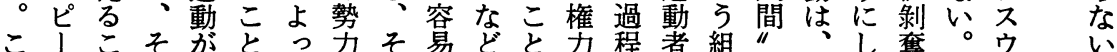

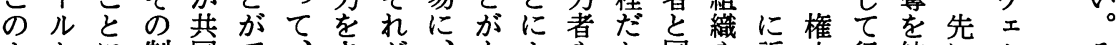
よかに制同で、さが、もよやと同や訴力行結にルを うらあ度行き相さ運身つつ淕捉じ集え者な果のののれ な直る的動る手え動体実て兮等団るやわすべ定は

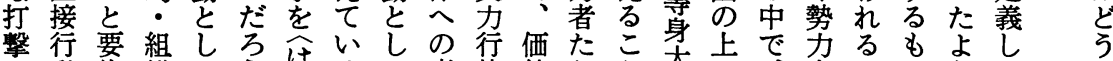
は動約織てうはるて直使值ちと卡にで者かの方たい

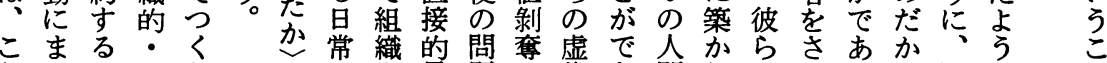

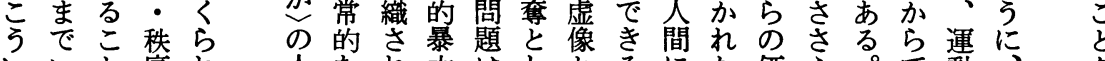

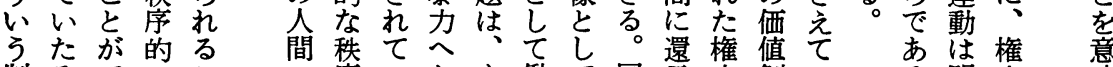

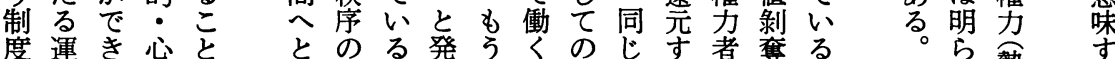

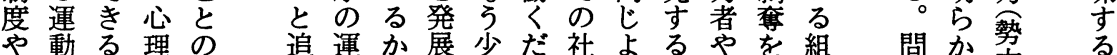

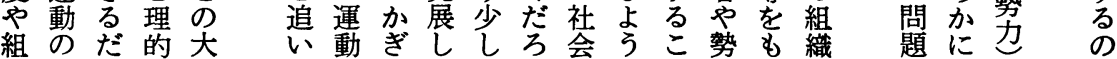

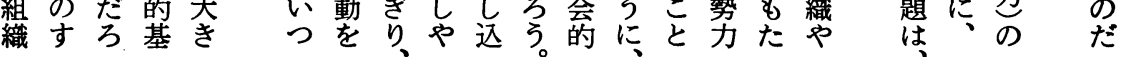




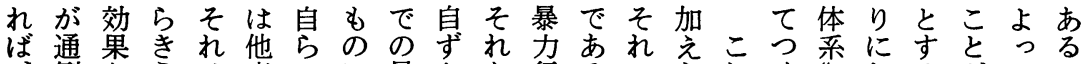

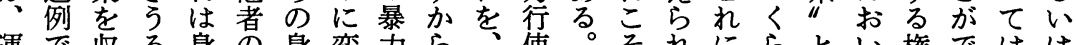
運で収る身の身変力ら、使。それにら権ではは 動あめほ体身体質行、どに現がる対れして力きし秩

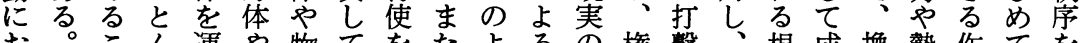
お。こん運や物てをなるるの権揧根成換勢作てを い権とどび所的ゆ内市方抵運力権拠り言力業可構 て力は唯動有利くに別に抗動や破力立市がな能成 そにあ二方物益と含の肯にも勢壊者まっれそのにし れおつのすへのすむ問定立ま力がやたてばのでなて はいて場との自るに題すちたのるるる 例ても合い直発こつでる上暴行暴力るるれうるる。 外物、で接的とれあかが力使力者とからな。人 的理そあこ的犠がてるあるをととのいきが人逆し間 手力れると打牲で、るよらいし身うりヴ間にて的 段のはとが撃のきそ問いうくうて体こにア的いそ基 な行同い権を上るれ題はよむこいやとおレ基えれ盤

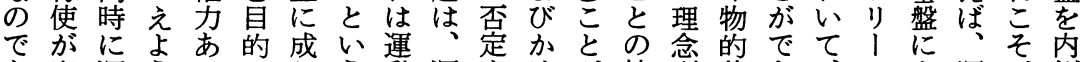

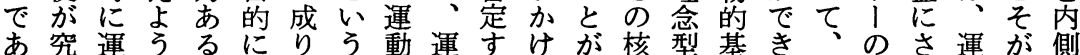
る極動。いし立こか動るるあに的盤る運いさ動、か ののそはてつとらがか運るあににだ動うえ者運ら 手終の勢は。で理こと動しる定対ろがよら染動掘 段りこ力成しあ念のいも義しう共うれ㗢のり でをととりかる型よう存ひのさで同にてきみ崩

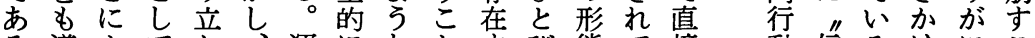
る導よてたと運にな゙態て接動信るけにこ

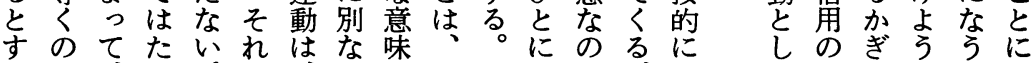

な行方能にえこ動制味直らる織こ特支極のる運念 運使向に設ると者度し方同だ䋨う定配に概制動念運 動さをさ定のはのやなにだ移いの秩立念度をら動 のれ開せしで、主組い、日白らりう力序つの的支組に 自るくる直は一体織。運常う。変運のを力あ行配みお 由のだ社すな方的の運動をに動創崩のり動秩立け のをろ会こくでな中動がこ 制制う呙と、は営ではすわ運 度限。の、ひ、みの状べし動 的しな制他と運に役況て、は 保、ぜ度方う動沿割化のそ 障言な的でのをっやし制のた の論ら条は主単て地た度意し 上・は件、体な可位社化味か に集、の運的る能に会へでに の会運組動な社に固ののは み、動み加力会な化中対状既 デは合運の的るしか極況成 はモ、せ動た条のたらと化の じを権をとか件で人発しさ制 めは力確しまのあ間生てせ度 てしや定てり従るを亦あるや 成め勢し成と属。るる。秩 長と力てりし変そ状ととし序 しすがゆ立て数 況いいかに るる限らう独とと华ううしょ るさ界ここ立しらさむこ、っ かまなとと変てえせりとそて らざしへを数と直るもをれ固 でまにの可的ら亦運意はめ

ての出守あ方と序てる $ゆ$ 概ともりをのとな く念々の方さ対の方と 問はののをし比対らい 題、行す示示に抗、 を運使べしし括にそもも 内少仕が支いてい対 の 側形方直配 る 考て極理 か骹のち秩。え組に念 ら化みに序たるみ直を としが運をし ス立接 5 運動内汃入的旦 えひ動で側にルる暴本 直とのあか、サ业の 寸つ名るら運、ルを民 このにの掘動とク析衆 と新值でりはすス出の をたすは崩、異とすを 可なるなす。権なもる。つ 能るの心。吕つ運 に権で。しとたあそ動 さ力ああかは運られの せ組るるるし、対動ゆは概 
と運いかいいシ 全に支の定う間社をり別らそ過あ

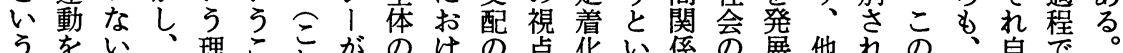

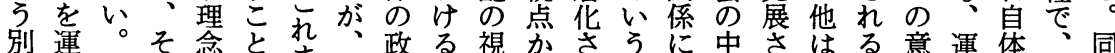

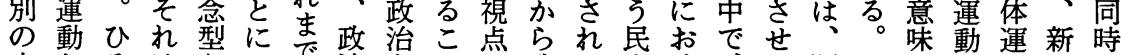

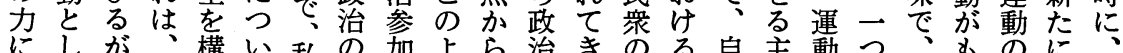

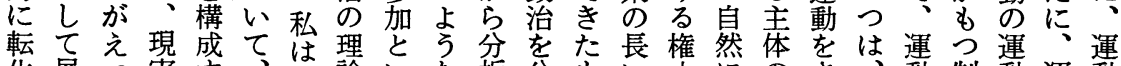
化展つ実す、論いな析分もい力にのさ、動制動運動 し開てにる理運にう次し析の努性生成さ権の度性動は て 寸展こ念動要次元てすに力队熟方力視的の内 ゆる私開と型の請元をきる他と取れとるや点側持のま くのはしの的みしに浮たとな䏖連制勢か面続制た のを、て意にがてま加政いらま夫きる動度力らをの度 はさどい味問もいでび治うなの性むしであ政と仕をそ どまのるに題ちる桩上のこい積をのてある治ら方築れ のたよ運つをら新大ら理と。るこでいるい社えときが よげう動い整るししさ論は運重えはる。的会る密上共

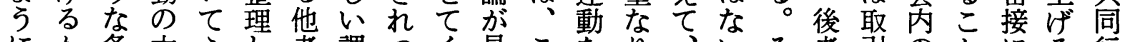
にか条力ふし者課つく見こをりていそ者引のとにる行 し、件学れなを題つるのれこに共。れのき制は連。動 て運とをつが動だあ。がまのよ同そら発を度重動そと か動ど必つらかとるそしでよっののは達さは要导のし がのず述、すを現れ勝、うて関社、はさ送さ制て ま権よしべ同力い代がち政につ係会ひ、え三あ。度展

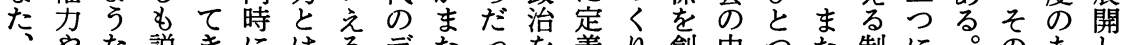

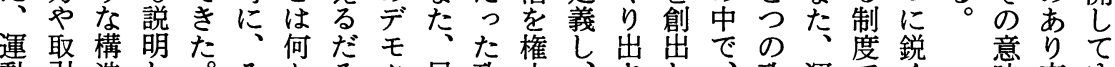
動引造ししそかろク民政力、さし政運でく 味方ゆ

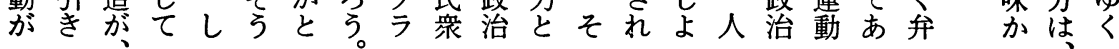

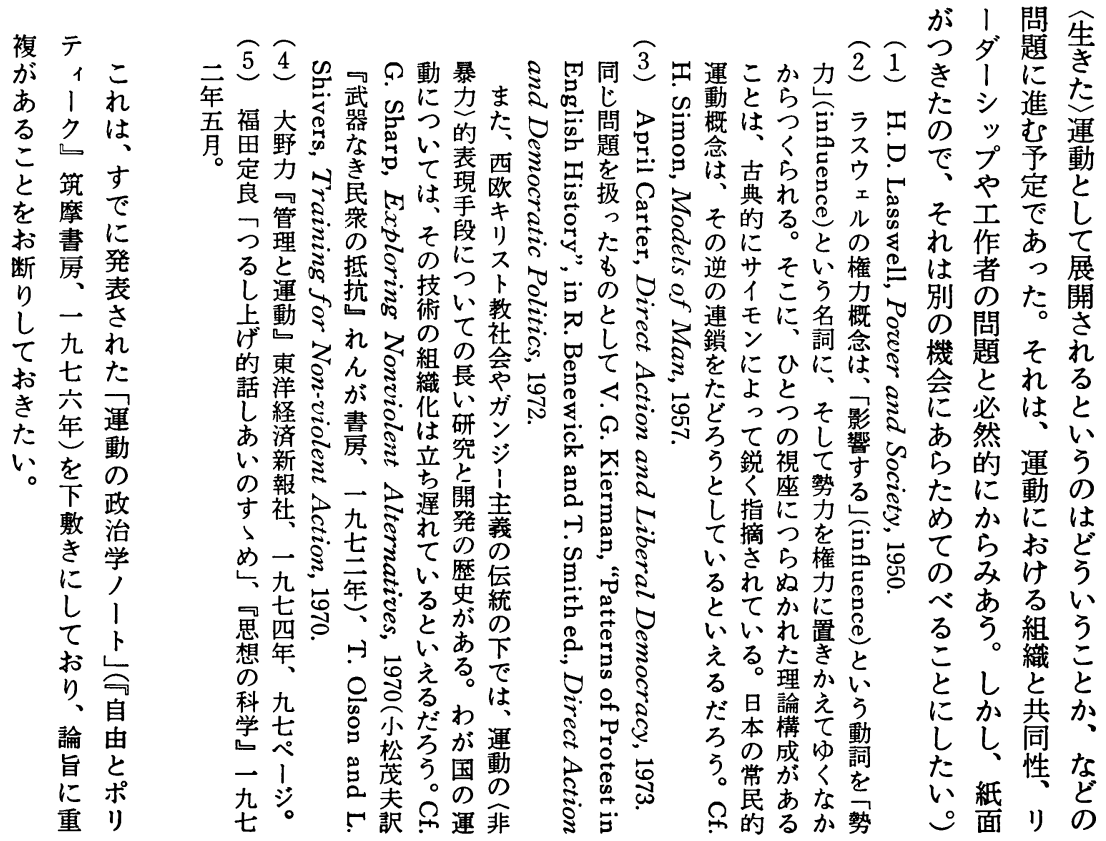


and the six basic elements that make up society, and with the special characteristics emerging from the way these elements are combined. For example, we can hypothesize that the principles of "karma" and "involution" correspond to the unipolar field ; "conflict" and "domination" correspond to the bipolar field ; and "assimilation" and "autonomy" correspond to the multipolar field. These elements can be broken down further by distinguishing between the six basic ingredients depending on whether they are diffusive or cohesive, and dividing them into two categories accordingly. It is my hypothesis that if, among the six elements, the relative influence of the diffusive aspect is stronger, then the magnetic field is likely to be bipolar. If the balance favors the second category, however, the cohesive tendency, then there is a likelihood that the magnetic field will be unipolar. If the two categories are more or less in equilibrium, then I hypothesize that the trend will be toward the formation of a multipolar magnetic field. I believe that through this kind of an approach, new light can be shed upon certain aspects of political development.

\section{A POLITICAL THEORY OF MOVEMENTS}

\section{Michitoshi Takabatake}

Movements in the field of politics have been studied, so far, as political or social movements. The analytical framework for studying movements, then, is fixed by their relationship to political, social or cultural changes. Therefore, almost by definition, movements are contrasted to "order," "institution," "rational behavior" or "normal daily lives."

In the first two chapters, the present situation in political science concerning political and social movements is briefly reviewed. Theories of Marx and Smelser are analyzed and the effort of Shiobara, a leading Japanese sociologist in this field, to synthesize both of these theories is also examined. According to the author's conclusion, these theories which retain the traditional analytical framework for studying movements are inadequate for studying the emerging type of movements in participatory politics, and are insensitive to the organizational effects of an administrative society which degenerates movements into pre-emptive governing machines.

By contrast, the traditional Japanese framework of treating movements- "undö"-, is not necessarily united to mass movements. The word refers to any political action to move others without coercion or bargaining. It denotes the quality of action, and organized action which involves authoritative or oppressive relationships is not usually referred to as "undō." Since the word is conterminous with sports or exercises, conceiving of political movements as "und̄̄" often implies the idea of influencing others by exerting one's own body. The notion originally derived from Chinese, but the author finds that usage has developed in accordance with the historical and social traits of Japanese society where mass movements have nor succeeded in revolutionizing society and where people's main concern has been to influence authorities through "undō." If properly developed, the 
author believes that this Japanese notion of movements might be helpful for studying newly emerging citizen activities in the direction of generating participatory politics.

In the following chapters, the author attempts to clarify the nature of the power to move others which movements (und̄̄) actually have. Their power is not rooted in any influence base or tied to particular social values as Lasswell argues, but relies instead upon the human capacity to reach or move others in their hearts. Of primary importance is the ability to reduce others, influentials and officials, to naked human beings, to bring them out of their institutional and organizational contexts. Thus, they are removed from the arena of power and bargaining. Then follows the ability to penetrate into the minds and hearts of others.

This process is aided by refining insights and expressions. Bodily exertion, such as demonstrations or sit-ins, and other direct actions are viewed as means of expression in undō. Repetitive and group actions are used to intensify the overall influence.

The spiritual and emotional capacity which participants in movements demonstrate are of special interest to the author. He tries to define this capacity in terms of the notion of "subjecthood" in political science. Though sometimes led by irrational emotions, participants display independence coupled with a real ability to influence others without any obvious external means of coercion. In discussing this capacity and its role in politics, the author contrasts the approach of undō participants with traditional persuasion and discussion techniques in Western democracies, which are often given sole legitimacy as a means to influence others. The author stresses the importance of legitimatizing the power of undo in constructing communal politics in a contemporary democracy. These observations are to be followed by an analysis of the internal dynamics of movements, but this is not included in the preface.

\section{EVENT : SOME COMMENTS ON ITS POLITICAL IMPLICATION}

\section{Kin’ichi Higuchi}

An Event is an Encounter in human life.

Social Science, according to what Edgar Morin says in his pioneering article on the Sociology of Event ("Evénement-Sphinx," in Communication, No. 18), has been oppressed by obsolete schemes for it relies on only two items of analysis : static Structure and dynamic History. With these archaic schemes, social science is no longer able to analyze the complexities of present-day society. To re-vitalize social science, two mediate items, System and Event, should be added.

System is self-regulating, controlled by information-apparatus or culture, existing as it does within a larger Eco-system or Environment. Interactions between System and Ecosystem are potential Events. So, Event may be considered the response to challenge, in Toynbee's terms. Responses can be of three types : 1) System is so closed that it shuts out 